\title{
1640 年北海道駒ヶ岳噴火による津波堆積物の分布と津波規模の推定
}

Tsunami deposits from the 1640 Hokkaido Komagatake eruption, north Japan: constraints on inundation heights and numerical simulation of volcanic debris avalanche-derived tsunami

\section{中西 諒* 岡村 聡**, ***}

Ryo Nakanishi ${ }^{*}$ and
Satoshi Okamura

2018 年 11 月 12 日受付.

2019 年 7 月 24 日受理. 東京大学大気海洋研究所

Atmosphere and Ocean Research Institute, Tokyo University, Chiba 277-8564, Japan

** 北海道教育大学

Hokkaido University of Education, Sapporo 002-8502, Japan

**** 北海道土質試験協同組合

Hokkaido Soil Research Co-operation, Sapporo 003-0831, Japan

Corresponding author: R. Nakanishi, r-nakanishi@aori.u-tokyo.ac.jp

\begin{abstract}
Coastal sediments in Uchiura Bay and along the Iburi coast, on the western part of the Pacific coast in Hokkaido, contain organic sediments intercalated with tsunami-derived sediments from a 17th-century tsunami event. The event layers show sedimentary features characteristic of a tsunami origin, including thinning of layers, sediment fining, and decreasing heavy mineral content in an inland direction. From Uchiura Bay to the western Iburi coast, the event layers are directly overlain by the 1640 Komagatake tephra (Ko-d). From the eastern part to the central part of the Iburi coast, the event layers deposit below the 1663 Usu tephra (Us-b), but there is almost no gap between them because there is only a very thin humus layer. We infer that the event layers record the tsunami caused by the $\mathbf{1 6 4 0}$ Komagatake eruption, because this eruption produced both a large tsunami and a large amount of tephra (Ko-d). Our numerical simulation based on the distribution of the event layers indicates that more than $1.2 \mathrm{~km}^{3}$ of debris formed an avalanche into the sea, causing a tsunami of Mt 7.9-8.2. The estimated run-up heights showed good agreement with the observed run-up heights from Uchiura Bay to the Shiraoi area of the Iburi coast.
\end{abstract}

Keywords: tsunami deposit, volcanic tsunami, 1640 Komagatake eruption, tsunami magnitude (Mt), numerical simulation, Hokkaido

\section{はじめに}

2018 年 12 月, インドネシアのスンダ海峡沿岸域を襲つ た津波はアナク・クラカタウの噴火に伴う山体崩壊によって 発生したとされている(Williams et al., 2019)。検潮記録に よる津波の高さは最大で $1.4 \mathrm{~m}$ とされたが，地震動が小さ いため避難が遅れ，24 分という速さで津波が襲い 400 人以 上の死者を出した．火山性の津波は発生頻度が低いものの, 一度発生すればその被害は甚大である。また歴史記録に残る 事例は限られているため, その規模や履歴を究明するために は周辺地域の津波履歴を示す堆積物の調査が不可欠である. 北海道においては古文書記録から, AD1640 年の駒ヶ岳噴 火にともなう山体崩壊によって発生した津波が, 内浦湾沿岸 に押し寄せ， 700 人以上の犠牲者を出したとされている(勝 井ほか, 1975). その津波痕跡は, 駒ヶ岳山麓の森町鷲の木 から内浦湾を挟む対岸の伊達市アルトリにおいて, 1640 年 噴火の駒ヶ岳 $\mathrm{d}(\mathrm{Ko}-\mathrm{d})$ テフラに覆われた縜〜砂層からなる 津波堆積物として確認されている(西村・宮地, 1998)。西 村・宮地 (1998) は山体崩壊による津波波高の数值シミュレー ションと津波堆積物の標高との比較をしているが, この計算 に用いられた山体崩壊量 $\left(0.1 \mathrm{~km}^{3}\right)$ は, その後, 駒ヶ岳噴火 に関する再検討によって 0.92-1.20 km³ と見積もられ (吉本
ほか, 2003), 当時の津波の規模はさらに大きかった可能性 がある. 一方で, この津波痕跡の指標となる Ko-d テフラの 分布範囲は限定的なため, この時の津波を裏付ける堆積物 は, 西村・宮地(1998)の報告を除くと, 登別市富岸におい て報告されているものに限られる(岡村ほか, 2012). 一方, 富岸の東方に位置する胆振海岸沿いの白老町からむかわ町 にかけて, 17 世紀に生じたとされる津波堆積物が標高 5-6 $\mathrm{m}$ (最大 $8 \mathrm{~m}$ 程度)に分布することが報告されているが(高清 水ほか, 2007; 岡村ほか, 2012; 高清水ほか, 2013; 中西ほ か, 2014), その波源については解明されていない. 最近, さらに南東部の日高町賀張においても 17 世紀の津波堆積物 が見つかつており (高清水ほか, 2017), 当時の津波の規模と 波源を特定するためには, これらの堆積物の対比がきわめて 重要な課題となっている. 北海道太平洋沿岸を襲つた 17 世 紀の津波の波源としては, 1640 年北海道駒ヶ岳噴火のほか, プレート境界型地震に由来すると考えられる 1611 年慶長津 波や，地震調査推進本部 (2017)が Mw 8.8 と想定している 千島海溝を震源とする津波が候補とされている(高清水, 2017).

本論では, 内浦湾沿岸から胆振海岸にわたつて広域的に野 外調査を行い, 各地点での津波堆積物の分布と堆積学的記載 を行った. そして, それらの堆積物の分布が 1640 年北海道 


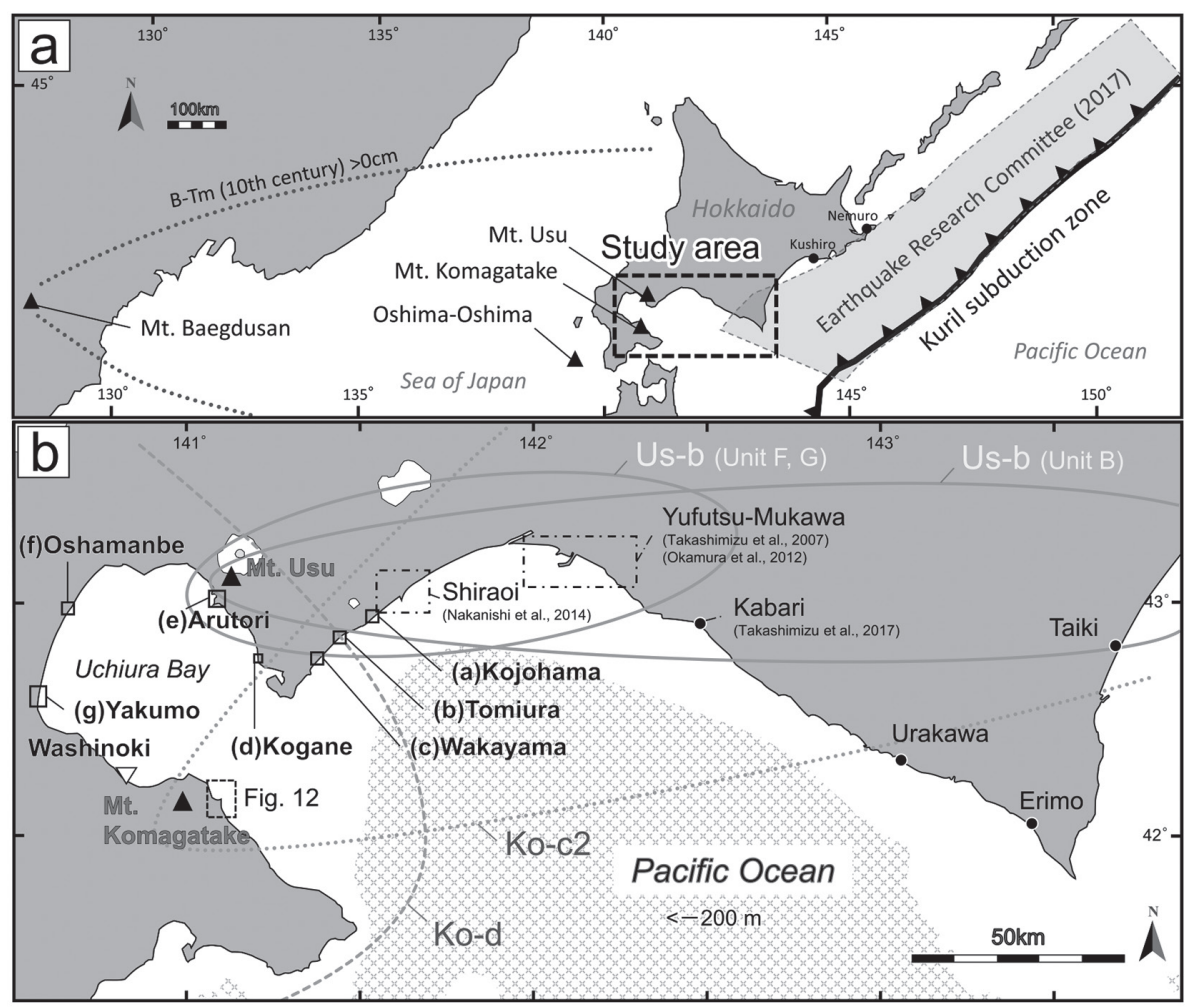

Fig. 1. (a) Map of the study area, showing the inferred earthquake source along the Kuril subduction zone (Earthquake Research Committee, 2017), and volcanoes that have produced regional tephras (Baegdusan, Komagatake, Oshima-Oshima, and Usu). The dotted line marks the B-Tm tephra depositional limit (Nakamura, 2016). (b) Map of the study area showing the distribution and sources of 17th-century tephra layers (Komagatake and Usu). Solid and dotted lines mark the tephra depositional limits (Nakamura, 2016).

駒ヶ岳噴火にともなう津波で説明可能かどうかを検証するた めに, 堆積学的・地形学的検討を行い現世の津波堆積物と比 較して浸水高を推定した. さらに，推定した遡上高と山体崩 壊による津波数值シミュレーションの結果とを比較検討し た. 最後に, 各地点の津波堆積物と千島海溝を震源とするプ レート境界型地震との関連についても触れる.

\section{調査研究方法}

野外調査では, 長さ $60 \mathrm{~cm}$ ・幅 $10 \mathrm{~cm}$ のハンディージオ スライサーと径 $7 \mathrm{~cm}$ のピートサンプラーを用い, 地質層序 の記載と各種分析用の試料採取を行つた. また, 泥炭やクロ ボク土が連続して堆積する湿地環境において見られる砂層を イベント砂層とみなし, その堆積構造, 偽礫や侵食面の有 無, 粒度などを記載した. 火山灰の分析については, 採取試 料の洗浄後, 鏡下で構成粒子の鑑定を行い, 分取した火山カ ラスについて, 12 時間 $400^{\circ} \mathrm{C}$ の脱水処理を施し, 北海道教 育大学札幌校の温度変化型屈折率測定装置を用いて屈折率を 測定した. 火山灰の同定は, 北海道内の主要テフラの火山ガ ラス屈折率の值 (Nakamura, 2016) と比較することによって 行つた. 粒度分析については, 砂層全体をバルク試料として 採取し，風乾した後(有機物との分離が難しい場合は $15 \%$ の過酸化水素で有機物を除去), 乾式篩い分け法 (1/2申階級) で行い, Folk and Ward(1957)にしたがって分級度 $\left(\sigma_{\mathrm{I}}\right)$ お
よび歪度 $\left(\mathrm{Sk}_{\mathrm{I}}\right)$ を求めた. 構成粒子の鑑定はイベント砂層と 周辺域の砂粒子について行つた. それぞれの試料から 1.5-2 $\phi$ サイズの粒子を篩いによって分取し, 実体顕微鏡で 200 個以上をカウントし, 構成粒子を, 黒色岩片, 白色岩片, 不 透明鉱物, 有色鉱物, 斜長石, 石英, 軽石, 火山ガラスの 8 種類に分類した. 海浜砂については, 砂層の堆積当時 (17 世 紀頃)の海浜砂と考えられる古浜堤砂も比較対象とした. 黒 色岩片としたものは多くが火成岩および泥岩片であり, 白色 岩片は珪質岩が大半を占めていたため, 白色岩片, 斜長石, 石英, 軽石, 火山ガラスを比重の小さなグループ $(\mathrm{w})$, それ 以外を比重の大きなグループ(b) に分類し, その合計比 $(w / b$ $\left.=\log _{10} \mathrm{w} / \mathrm{b}\right)$ を算出し, 砂層の組成変化を検討した. この值 が大きくなると無色鉱物や軽石などの割合が高く, 運搬・堆 積作用にともなう堆積物の軽量化傾向を示す. 測線断面図の 標高は, 測量基準点における国土地理院の航空レーザー測量

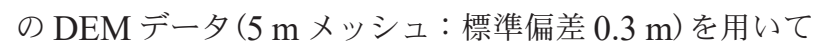
求めた.

\section{調査地域と鍵層テフラの同定}

本調査地域は, 胆振海岸の白老町虎杖浜から内浦湾沿岸 にいたる太平洋沿岸域であり, 8 箇所で測線を設定した (Fig. 1). 調査地の選定は, 人為的な改変地域を避けるために, 国土地理院の DEM データと空中写真を参考にした. 調査 


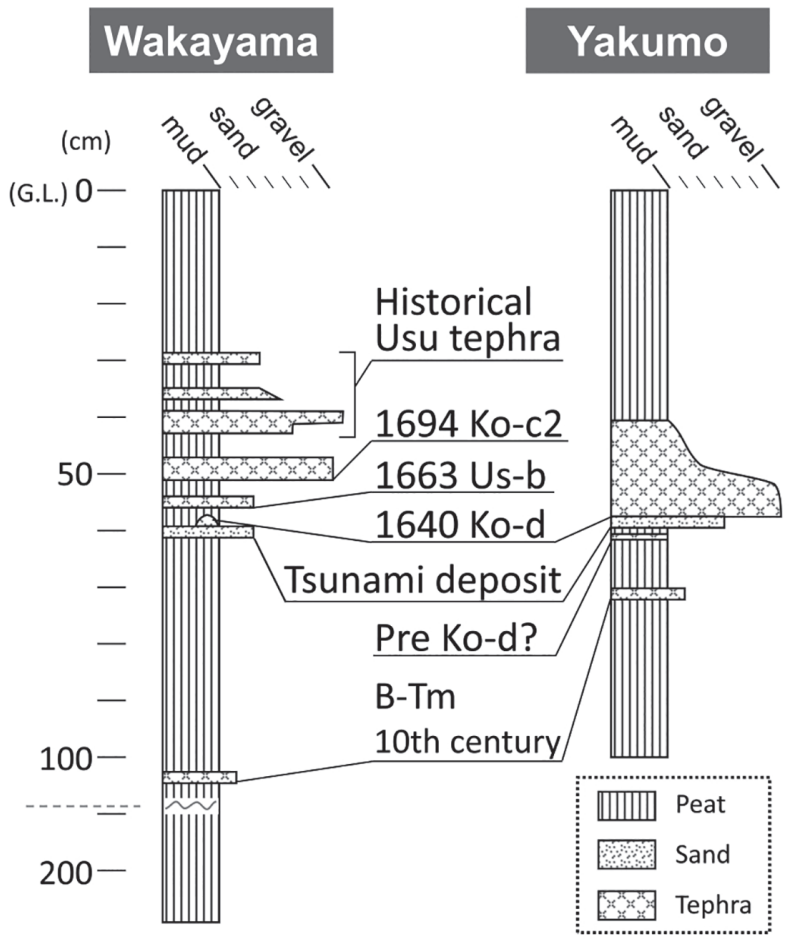

Fig. 2. Stratigraphic columns of the Wakayama (WY-8; Fig. 8) and Yakumo (YK-A; Fig. 4g) areas.

地の地形・地質は, 標高 3-6 m の浜堤間や砂丘の背後に存 在する泥炭湿地を主体とし，泥炭・クロボク土の有機質層か らなり，浜堤に近い場所ではクロスナ層の層相を示す．人為 改変を受けていない地域では, 鍵層として, 内浦湾の東側か ら胆振海岸では 1694 年北海道駒ヶ岳噴火による駒ヶ岳 c2 (Ko-c2) テフラおよび 1663 年有珠山噴火による有珠 b (Usb) テフラ, 内浦湾の西側では 1640 年駒ヶ岳 $\mathrm{d}($ Ko-d $)$ テフ ラが確認される (Fig. 1). 内浦湾西部と胆振海岸南西部の代 表的な柱状図を Fig. 2 に示し，以下に主な鍵層テフラの特 徵と火山ガラスの屈折率測定結果を示す (Fig. 3).

Ko-c2 : 淘汰がよく, 白色軽石と有色鉱物が特徵的なゴマ シオ状の層相を呈する. 火山ガラス > 斜長石 >輝石類の構成 粒子からなる. 火山ガラスの屈折率は 1.495-1.496 を示し, Nakamura (2016)の Ko-c2 (1.496-1.498)の特徵と近似す る.

Us-b : 本テフラは地域によって層相が異なり, 白老地域 では淘汰の良い白色軽石からなる. 少量の角閃石を特徵的に 含み，火山ガラスの屈折率は 1.491 付近に集中する. Us-b テフラは, プリニアン噴出物 (Unit B) と水蒸気マグマ噴出 物 (Unit $\mathrm{C} \sim \mathrm{G}$ ) に大別され (Nakamura, 2016), 白老地域 (虎杖浜)で見られるテフラは，分布および火山ガラスの屈折 率から Unit B (1.491)に対比される (Figs. 1, 3)．登別から 伊達にかけて分布する本テフラは，淘汰が悪く岩片が目立つ 層相や桃〜褐色の細粒火山灰層からなり，本テフラ層下位の 火山ガラスの屈折率は 1.485 付近と低い值を示しているこ とから, Unit F (1.483-1.486; Nakamura, 2016)に対比さ

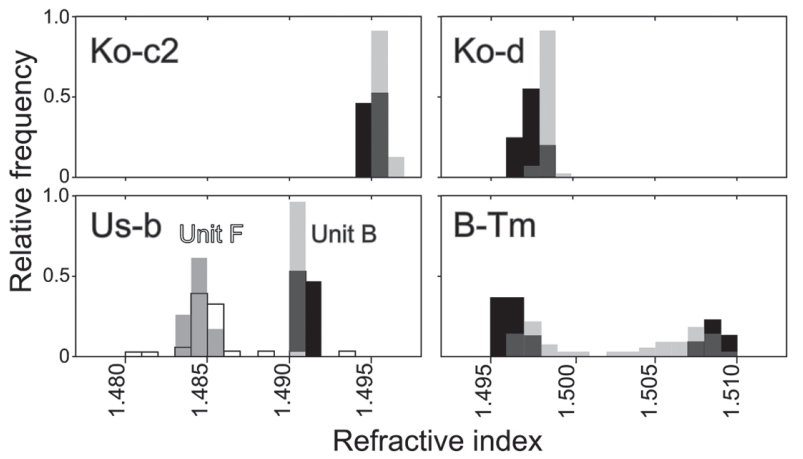

Fig. 3. Relative frequency histograms of the refractive indices of dehydrated volcanic glass shards from the western part of the Pacific coast in Hokkaido (Ko-c2, Us-b Unit F, Ko-d, and B-Tm tephras from Wakayama; Us-b Unit B tephra from Kojohama). Data in gray are from Nakamura (2016).

れ，その上位層は Unit G であると考えられる.

Ko-d：内浦湾西側では淘汰の良い黄白色軽石層からなる が，東側では白色の細粒火山灰層がパッチ状に分布するのみ である. 火山ガラス $>$ 斜長石 $>$ 輝石類の構成粒子からなる. 火山ガラスは発泡の良いスポンジ型からバブルウォール型の 特徵的な形態を示し, 屈折率は1.497-1.499に集中し, Nakamura (2016)の Ko-d テフラの值 (1.498-1.499) と近 似する，八雲および長万部では，Ko-d 軽石層とイベント砂 層の下位には数 $\mathrm{mm}$ の有機質層をはさんで火山灰質薄層が 不連続に認められる. この薄層は Ko-d テフラと類似の構成 粒子・火山ガラスの屈折率を示し, 1640 年駒ヶ岳噴火によ る山体崩壊以前の比較的近い時期に活動した噴出物の可能性 がある.

B-Tm : 本テフラは内浦湾〜胆振海岸の全域にみられ, 層 厚 1-2 cm の白色から橙白色を呈する細粒火山灰からなる. 火山ガラスは全体の $90 \%$ 以上を占め, 屈折率は $1.496-$ 1.498 と 1.508-1.510 のバイモーダルな值を示し, Nakamura(2016) の B-Tm テフラの值(1.496-1.510)に近似す る.

\section{各調査地点のイベント堆積物の特徵}

\section{白老町虎杖浜 (Fig. 4a)}

本地域では海岸線に平行に続く $6 \mathrm{~m}$ ほどの浜堤と堤間湿 地を切る方向の測線を設定した (Figs. 4a, 5). 本地域の海岸 地形は，非常に急勾配をなす砂浜とその背後の約 $200 \mathrm{~m}$ 内 陸まで達する浜堤に区分できる. 本地域周辺の 1946 年に撮 影された空中写真 (国土地理院)では現在より数十 $\mathrm{m}$ 沖合に 汀線が存在していることから, 海浜侵食が急激に進行してい る.

層序は下位から扁平な中礫層, 数十 $\mathrm{cm}$ 層厚の碩混じり有 機質層, イベント砂層, 数 $\mathrm{mm}-2 \mathrm{~cm}$ 層厚の有機質層を介 して粗粒な軽石からなる Us-b テフラ (20-30 cm 層厚)がみ られ，表層付近が砂質土袞となっている．イベント砂層の最 も厚い地点は浜堤背後に位置する $\mathrm{KJH}-2$ であり，本層の堆 

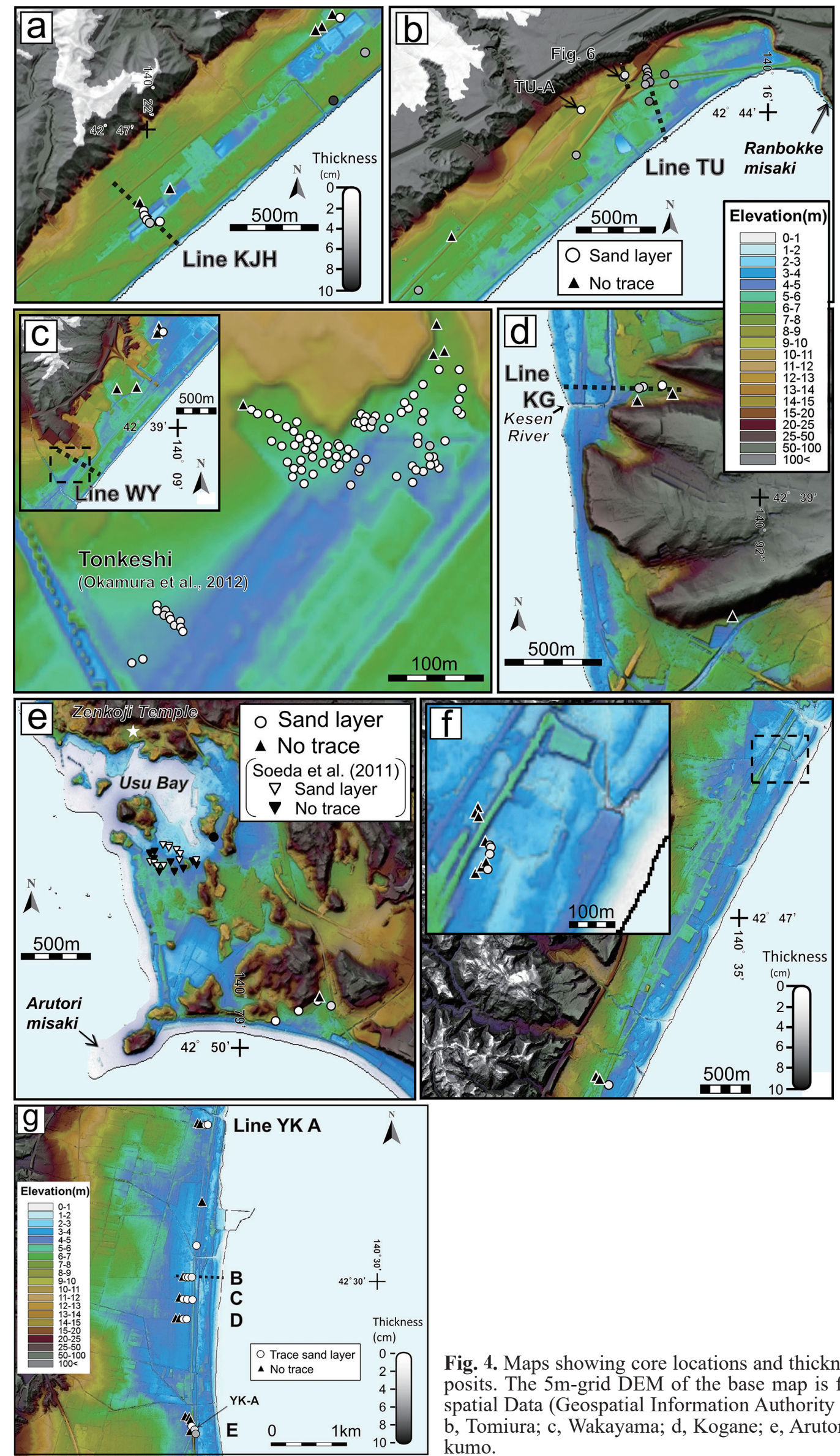

Fig. 4. Maps showing core locations and thicknesses of the tsunami deposits. The 5m-grid DEM of the base map is from Fundamental Geospatial Data (Geospatial Information Authority of Japan). a, Kojohama; b, Tomiura; c, Wakayama; d, Kogane; e, Arutori; f, Oshamanbe; g, Yakumo. 


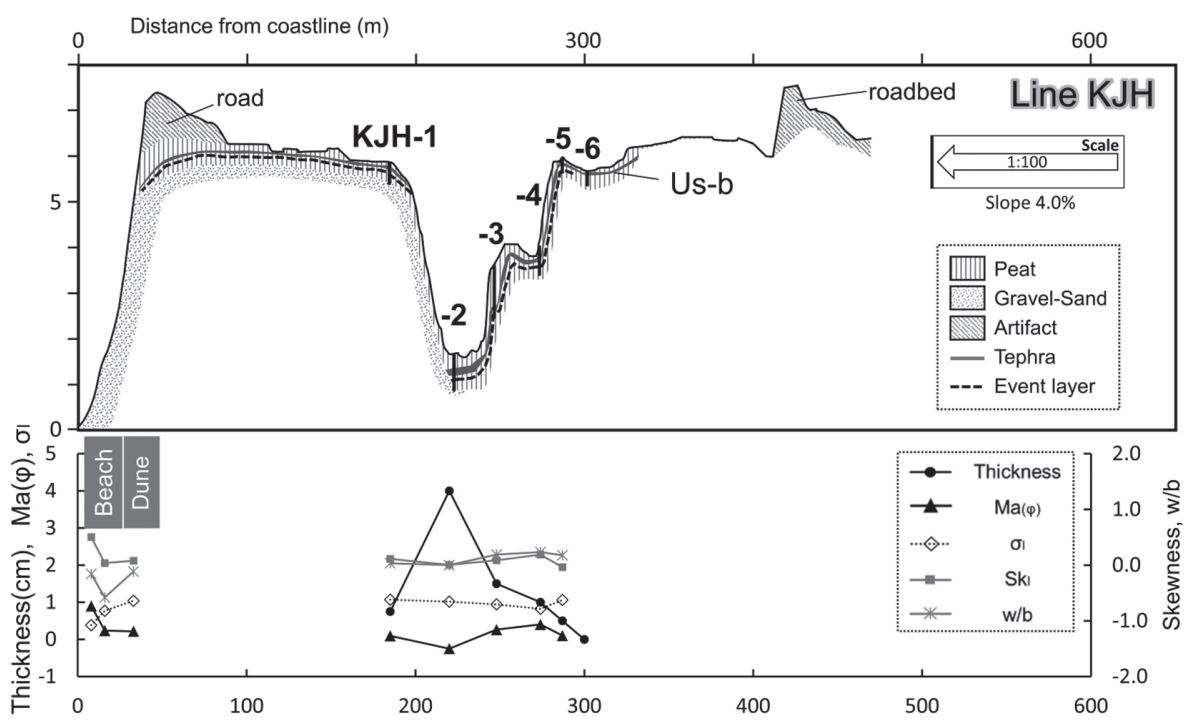

Fig. 5. Upper: detailed stratigraphic cross-section along Line KJH in Kojohama. Lower: lateral variations in the thickness and particle characteristics of the tsunami deposits and beach sand around the beach. Ma $(\phi)$, arithmetic mean diameter; $\sigma_{\mathrm{I}}$, inclusive graphic standard deviation; SkI, inclusive graphic skewness; $w / b$, mineral composition.

積構造は上位に向かって逆級化から正級化構造を示す，同様 の堆積構造は, 本地域の北東 $17 \mathrm{~km}$ に位置する社台のイベ ント砂層(中西ほか, 2014)にも認められる. イベント砂層の 層厚は内陸に向かって急激に薄くなり $\mathrm{KJH}-5$ と KJH-6 の 間でせん滅する.

粒度分析の結果, イベント砂層を構成する粒径は平均 $0 \phi$ と現在の海浜砂と比べて粗いが, $w / b$ はイベント層が有意に 軽量であることを示している．さらに内陸に向けてはわずか に細粒・軽量化傾向が見られた (Fig. 5). 鏡下観察の結果, イベント砂層の構成粒子は有色鉱物と黒色岩片を主体とし浜 堤砂と類似していることがわかった。. イベント砂層の分布最 高位は標高 $5.6 \mathrm{~m}$ である. 本地域周辺には河口や河川跡が 存在しないことから、イベント砂層は 17 世紀当時の浜堤を 乗り越えて遡上したと判断される. KJH-1 では土袞化した 浜堤砂の上位にイベント砂層が重なりその上位に Us-b テフ ラが堆積していることから，17世紀から現在にかけて浜堤 の形状は大きく変化していないことがわかる. 17 世紀当時 の浜堤の標高はイベント層やテフラ層を差し引くと約 5-6 $\mathrm{m}$ と考えられる.

\section{登別市富浦(Fig. 4b)}

現在の海岸線付近は, 盛り土によって高まりが作られてい るが, 海岸線から約 $200 \mathrm{~m}$ までは砂質堆積物のみが分布し ており砂浜地形が広がっていたと考えられる。 その背後はク ロスナ層の上位に $1 \mathrm{~m}$ 程度の泥炭層が発達しており, 内陸 に向かいその厚さが増していく. 海岸から 400-900 m ほど 内陸にはクッタラ火山噴出物の急崖が存在する.

層序は下位から泥炭層中に層厚 3-7 cm のイベント砂層 (深度約 $60 \mathrm{~cm}$ ), 数 $\mathrm{mm}$ から数 $\mathrm{cm}$ 層厚の泥炭層を挟夕色 調と分級度の異なる複数ユニットからなる層厚数 $\mathrm{cm} の$ Us-b テフラが堆積している. 本砂層の上位にはパッチ状の

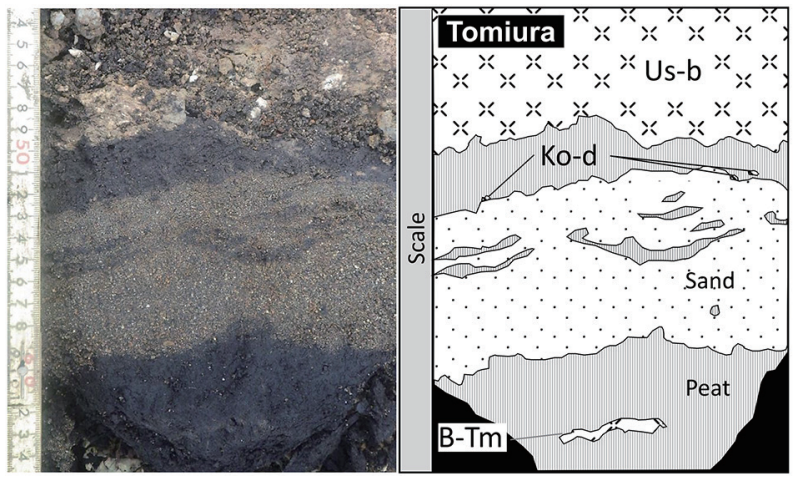

Fig. 6. Photograph and sketch of the tsunami deposits at location TU-8 in Tomiura.

Ko-d テフラが見いだされる (Fig. 6)，イベント砂層の層相 は, 虎杖浜地域と同様に, 下位から逆級化, 正級化構造を示 すことが多く, TU-5 と TU-8 においては下位に逆級化構造 を持つ粗粒な砂層, 中位に不連続な有機質層をはさんで細粒 砂サイズの上位砂層へと変化する. 中位の有機質層は, 下位 の砂層と泥炭との境界に侵食痕や偽碟が見られることから， 下位の泥炭層の再堆積相と考えられる.

測線 TU では内陸に向かって薄層化傾向を示す (Fig. 7). 鏡下観察の結果, イベント砂層の構成粒子は岩片, 有色鉱 物, 石英・長石からなり, 海浜砂とよく似た組成を示す. ま た, 測線上では内陸に向けて粒度や構成物などに大きな変化 は見られず，イベント砂層はクッタラ火山噴出物からなる急 崖付近まで分布している. TU 測線から $400 \mathrm{~m}$ 西側の地点 (TU-A)ではイベント砂層が泥炭層中にレンズ状に確認され る. TU-A 地点での粒度組成は, 粗粒部と細粒部のバイモー 


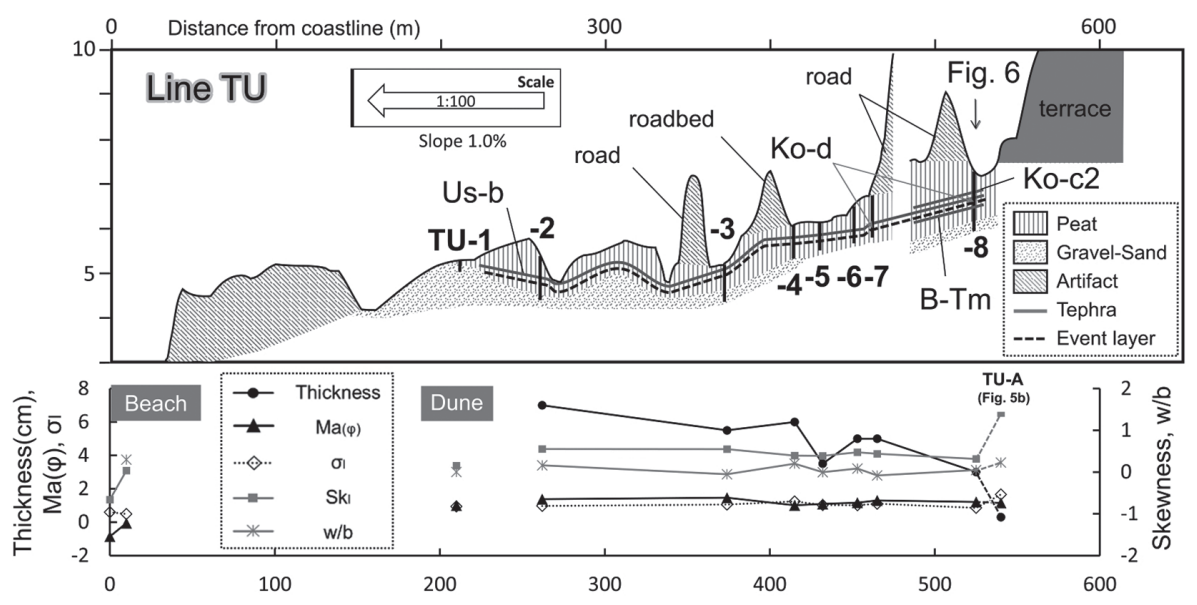

Fig. 7. Upper: detailed stratigraphic cross-section along Line TU in Tomiura. Lower: lateral variations in the thickness and particle characteristics of the tsunami deposit and beach sand around the beach. Abbreviations as in Fig. 5.

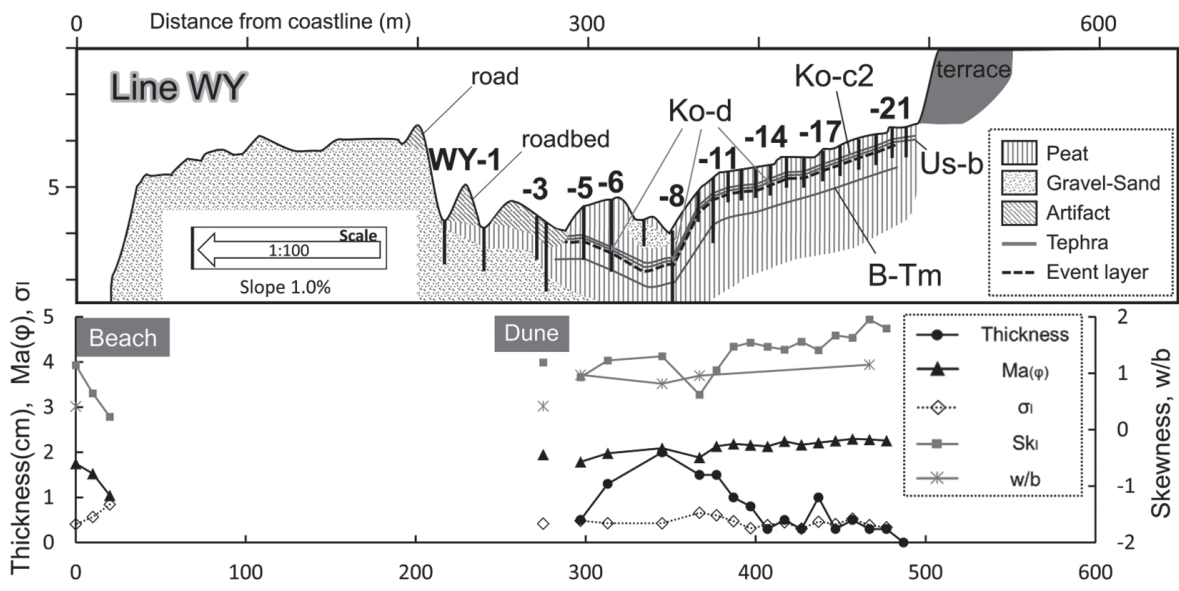

Fig. 8. Upper: detailed stratigraphic cross-section along Line WY in Wakayama. Lower: lateral variations in the thickness and particle characteristics of the tsunami deposit and beach sand around the beach. Abbreviations as in Fig. 5.

ダルな特徵を示し，粗粒成分のほとんどは円磨された軽石で あり，細粒成分は $2.1 \phi$ にピークを持つ砂粒子であった. イ ベント砂層中の粗粒な軽石は, 未脱水試料で 1.510 以上と 高い屈折率を示すことから, 本地域において分布している クッタラ火山噴出物 (屈折率 1.500-1.514; 胆振団体研究会, 1990)の再堆積物であると考えられる. TU-A 地点の標高は $8.4 \mathrm{~m}$, 海岸線からの距離は $500 \mathrm{~m}$ であった.

\section{登別市若山(Fig. 4c)}

本地域は, 1-2 列からなる浜堤列(現標高約 $6 \mathrm{~m}$ ) の後背 湿地にあたり, 未分解の腐植層が $2 \mathrm{~m}$ 以上発達している. この泥炭湿地では $210 \mathrm{~cm}$ の深度までピートサンプラーを 用いて観察を行った (Figs. 2, 8; WY-8)。 その層序は下位か ら未分解腐植層, 10 世紀頃を示す B-Tm テフラ(約 $1 \mathrm{~cm}$ ), 層厚 40-60 cm の腐植層の上位にパッチ状の Ko-d テフラ と接した層厚数 mm-4 cm のイベント砂層 (深度約 $60 \mathrm{~cm}$ ) があり, 数 $\mathrm{cm}$ の層厚の場合には級化構造を示す.さらに上 位には Us-b テフラ(層厚約 1-3 cm), Ko-c2 テフラ(層厚
約 2-4 cm), 有史時代とみられる三層の有珠山テフラがみ られる. 深度約 $2 \mathrm{~m}$ まで認められる腐植層は, 分解がやや 良くなる部分も含みながら連続的に堆積しており, 介在する テフラの噴出年代をもとに算出される腐植層の堆積速度は約 $0.1 \mathrm{~cm} /$ year と見積もられる. B-Tm テフラの下位には $120 \mathrm{~cm}$ 以上の連続的な腐植層のみが堆積しており, 10 世 紀から遡ること約 1200 年前 $(2200 \mathrm{yBP})$ まではイベント砂 層の痕跡がみられない.

本地域の 100 箇所以上の詳細なハンドコアリング調査の 結果 (中西ほか, 2018), イベント砂層の分布の特徵は, 本地 域の南西約 $300 \mathrm{~m}$ に位置する富岸川から北東方向に続く低 地で厚い傾向が見られ (Fig. 4c), WY 測線でみると, 層厚 は海側から一様に減少していくのではなく, 低地で厚く (WY-8 付近), 陸側(WY-5 方向) と海側 (WY-10 方向)の両 方向に減少していく傾向がある (Fig. 8). イベント砂層の分 布限界(WY-21：標高 $5.8 \mathrm{~m}$, 海岸線から $490 \mathrm{~m}$ ) 付近では, 石英・長石類が約 $90 \%$ 占めるようになり, 最も細粒な海浜 


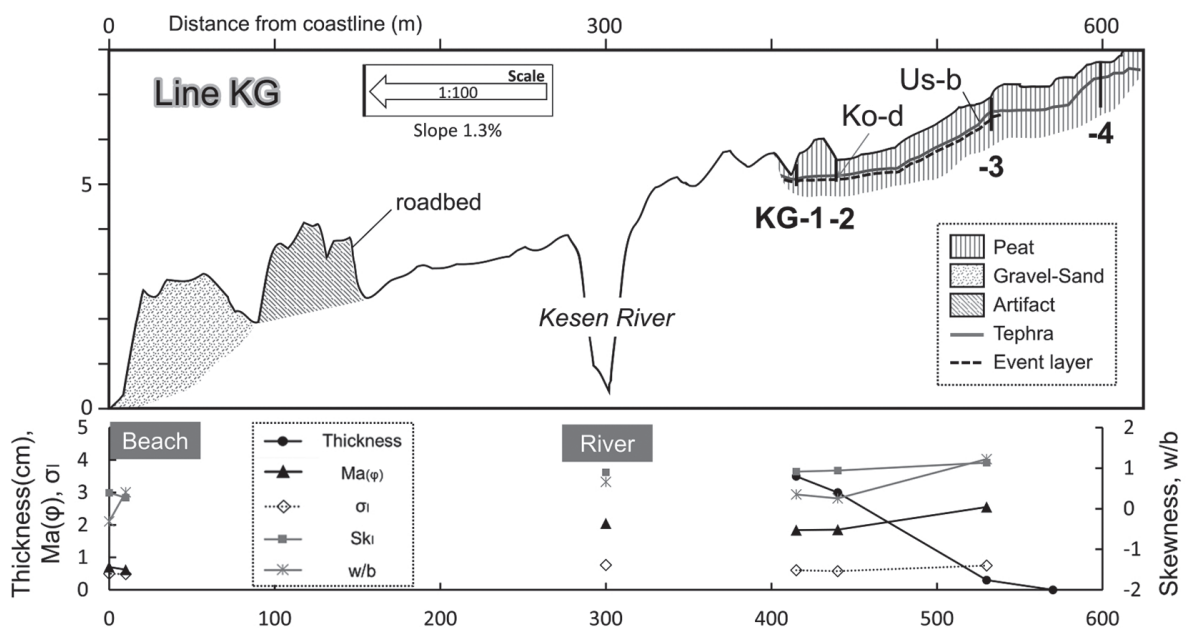

Fig. 9. Upper: detailed stratigraphic cross-section along Line KG in Kogane. Lower: lateral variations in the thickness and particle characteristics of the tsunami deposit, beach and river sand around the area. Abbreviations as in Fig. 5.

砂と比較しても約 $1 / 2 \phi$ の細粒化傾向が認められる(Fig. 8). 本地域のイベント砂層は, 平均すると層厚 $1-2 \mathrm{~cm}$ と薄く 非常に淘汰が良い。

\section{伊達市黄菳 (Fig. 4d)}

本地域の測線 KG(Fig. 9) では，海岸から約 $300 \mathrm{~m}$ 内陸 側に位置する気仙川が海岸線と平行に流れており，その背後 に湿地が形成されている. 本地域では層厚数 $\mathrm{cm}$ の Us-b テ フラが見られ，その下位(深度約 $40 \mathrm{~cm}$ ) に，パッチ状の Ko-d テフラに覆われたイベント砂層が認められる．本砂層 は最大層厚 $4 \mathrm{~cm}$ で正級化構造を示す.

構成粒子は, 輝石類と岩片が主体 $(\mathrm{KG}-1: w / b=0.4)$ を なす海浜砂と河川砂に類似の特徵から，もつとも内陸側 (KG-3) では軽石と火山ガラスが 3 割以上を占めるようにな り $(w / b=1.2)$, 内陸側で軽量化する傾向が見られる. 砂層 中の軽石および火山ガラスの屈折率は 1.480-1.496 と幅広 <, 周辺のテフラ層との対比は困難である. イベント砂層の 平均粒径は $1.7 \phi$ にピークを示し, 海浜砂のピーク $(0.7 \phi)$ と 気仙川河川砂のピーク $(2.3 \phi)$ の中間的な特徵をもつ.さら にイベント砂層の有色鉱物は約 20\% であるのに対し，海浜 砂が $30 \%$ 以上，河川砂は $10 \%$ 以下であり，本層が海浜砂 と河川砂の中間的な特徵を示す。イベント砂層は海岸から $520 \mathrm{~m}$ (標高 $6.4 \mathrm{~m}$ ) 付近で砂混じり泥炭層に変化し, $600 \mathrm{~m}$ (標高 $7.2 \mathrm{~m}$ ) 付近ではせん滅する. 測線の北側約 $3 \mathrm{~km}$ の稀 府においてもイベント砂層が認められ，その分布は海岸から $330 \mathrm{~m}$ (標高 $6.6 \mathrm{~m}$ ) 付近まで追跡できるが, $470 \mathrm{~m}$ (標高 $9.3 \mathrm{~m}$ ) 付近では認められない. 一方, 測線 $\mathrm{KG}$ から北方向 $2 \mathrm{~km}$ の地点では，海岸から $20 \mathrm{~m}$ (標高 $7 \mathrm{~m}$ ) 付近の段丘面 上で Us-b テフラが観察されるが，その下位にイベント砂層 は認められない.

\section{伊達市アルトリ恋人浜(Fig. 5e)}

アルトリ岬東方の恋人浜の露頭においてイベント砂層が確 認される. 本地域には, 約 7000-8000 年前に生じた有珠火 山の山体崩壊による善光寺岩屑なだれ堆積物が広がり，流れ
山地形を作っている(曽屋ほか, 2007). 岩屑なだれ堆積物は 洞爺火砕流堆積物や有珠外輪山溶岩からなり，それらを覆う 有機質層中に下位から駒ヶ岳 $\mathrm{g}(\mathrm{Ko}-\mathrm{g})$ テフラ(層厚 1-3 $\mathrm{cm})$, 約 $62 \mathrm{~cm}$ の泥炭層の上位に B-Tm テフラ, 約 $26 \mathrm{~cm}$ の泥炭層の上位に層厚数 $\mathrm{mm}$ のイベント砂層, パッチ状の Ko-d テフラ(層厚約 $1 \mathrm{~cm}$ ), 約 $1 \mathrm{~cm}$ の腐植層を挟んで層 厚十数 $\mathrm{cm}$ の Us-b テフラが堆積している.

本地域の海浜砂は有色鉱物と岩片が 7 割, 無色鉱物が 3 割の構成粒子を示すが, イベント砂層の構成粒子は, 海側で 石英主体，内陸側では軽石主体へと変化する．砂層中に見ら れる軽石はもろく円磨されており, 火山ガラスの屈折率は 1.496-1.498 を示し近隣のいずれの有史時代テフラ層とも 対比することができない。本地域周辺で砂層が確認できる海 岸線からの距離と堆積面の標高は, $75 \mathrm{~m} ・$ 標高 $12.0 \mathrm{~m}$, $255 \mathrm{~m}$ ・同 $9.8 \mathrm{~m}, 285 \mathrm{~m}$ ・同 $12.1 \mathrm{~m}$ であり, さらに内陸 側の地点 $(315 \mathrm{~m}$ ・標高 $12.6 \mathrm{~m})$ では砂層は認められない.

\section{長方部中ノ沢 (Fig. 4f)}

浜提 (現標高約 $4 \mathrm{~m}$ ) の背後に約 $200 \mathrm{~m}$ の範囲で低地 (砂 碩質)が続き, さらに内陸側には泥炭湿地が存在する. 泥炭 湿地の地表下約 $40 \mathrm{~cm}$ に褐色を呈する細粒で層厚 1-2 cm のイベント砂層がみられ，その上位に極細粒から中粒の Ko-d テフラが数 $\mathrm{cm}$ 腐植層を挟まず堆積している. 海岸付 近では, イベント砂層の下位に砂質の腐植層(層厚約 $10 \mathrm{~cm})$, 浜堤砂が続く.

Ko-d テフラ直下のイベント砂層は, 海浜砂と同程度の粒 度 (2.2-2.3申) を示し，石英と円磨された軽石が主体であり， 本地域周辺の海浜砂が石英, 長石, 輝石類, 角閃石類で構成 されているのとは異なる. 砂層に含まれる軽石の屈折率は 1.494-1.497 を示すため，近隣のいずれの有史時代テフラ 層とも対比することができない，本イベント砂層は分布範囲 が限定的であり，確認できる分布限界は，海岸から $320 \mathrm{~m}$, 標高 $3.7 \mathrm{~m}$ 付近であった. 


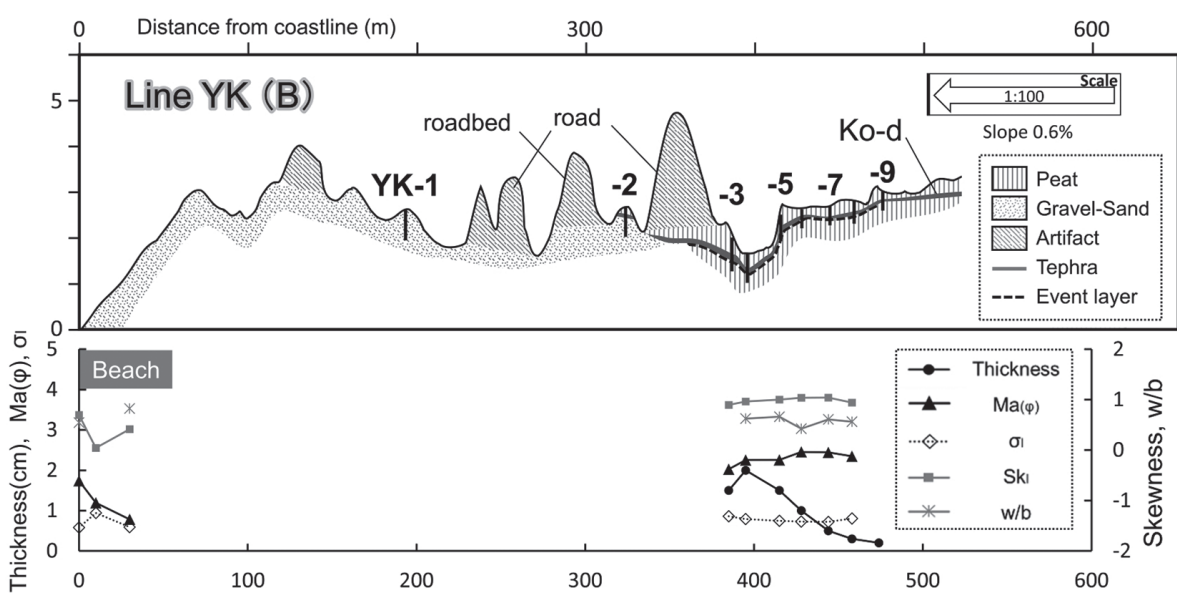

Fig. 10. Upper: detailed stratigraphic cross-section along Line YK in Yakumo. Lower: lateral variations in the thickness and particle characteristics of the tsunami deposit and beach sand around the beach. Abbreviations as in Fig. 5.

Table 1. Maximum distribution height and distance from the present shoreline of the tsunami deposits in Yakumo. Present dune heights are shown for comparison.

\begin{tabular}{ccccccc} 
Line No. & A & B & C & D & E & Ave. \\
\hline Deposition elevation (m.a.s.I.) & 3.8 & 2.4 & 2.8 & 3 & 3.7 & 3.1 \\
Distance of deposition limit (m) & 270 & 410 & 480 & 470 & 380 & 402 \\
\hline Dune height (Max; m.a.s.I.) & 4 & 4 & 4 & 4 & 4 & 4 \\
Dune height (Min; m.a.s.l.) & 4 & 2 & 2 & 2 & 1.5 & 2.3
\end{tabular}

\section{八雲町 (Fig. 4g)}

本地域では，1-2 列からなる浜提列 (現標高 2-4 m) の背 後に平坦な泥炭湿地が広範囲に存在する.ここでは海岸線に 沿う南北 $4.5 \mathrm{~km}$ の範囲で 5 つの測線を設けて調査した (Fig. $4 \mathrm{~g})$.

本地域の層序は, 泥炭層中に下位から B-Tm テフラ (深度 $50 \mathrm{~cm}$ ), 最大層厚 $5 \mathrm{~cm}$ のイベント砂層 (Figs. 2, 10), 腐 植層を挟まず層厚約 $15 \mathrm{~cm}$ の Ko-d テフラ, 層厚 20$40 \mathrm{~cm}$ の泥炭層 (一部は耕作土)が堆積する.

イベント砂層の構成粒子は黒色岩片が 5 割を占め, 次い で長石, 約 1 割の石英からなり, 海浜砂と類似の組成を示 すが，海浜砂より石英や軽石の割合が高い傾向がある。ま た，特徵的に海綿骨針を多数含む． 砂層中の軽石はよく円磨 されており，完新世で報告のあるどのテフラの屈折率よりも 低く值のばらつきが大きい. 本砂層の構成粒子は, $w / b=$ 0.5 (YK-3) から 0.8 (YK-8)へと内陸に向かって軽量化傾向 を示す. イベント砂層の平均粒径は, 最も細粒な海浜砂と比 べても $0.5 \phi$ 程度細かく, 内陸方向にわずかな細粒化傾向が 認められる (Fig. 10)．5つの測線で比較すると，イベント 砂層の分布限界では，標高が高ければ現海岸線からの距離が 短く，標高が低ければ内陸まで及んでいる傾向が読み取れる (Table 1). 本砂層は, 平均すると標高 $3 \mathrm{~m}$ 前後, 現海岸線 から約 $400 \mathrm{~m}$ でせん滅することがわかる．標高 $4 \mathrm{~m}$ 前後の 浜提のすぐ内陸側にはイベント砂層が認められない $(\mathrm{YK}$ A-YK B 間 ; Fig. 4g) ことから, 本砂層は浜堤の比較的低

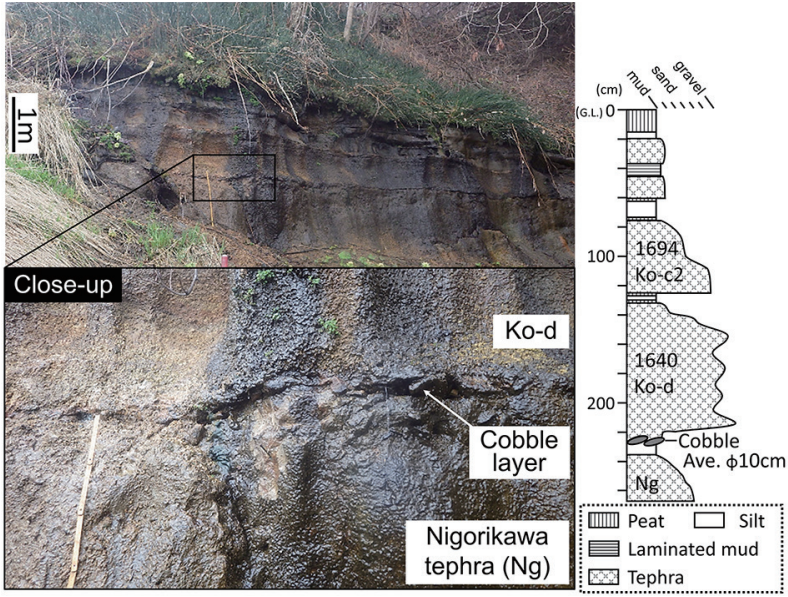

Fig. 11. Photograph and stratigraphic column of tsunami deposits (cobble layer) in Washinoki.

い場所や河川から浸入した可能性が高い。

なお，本地域から南東方向約 $10 \mathrm{~km}$ の八雲町野苗生右岸 の河岸段丘上(海岸から $240 \mathrm{~m}$, 標高 $6.5 \mathrm{~m}$ ) では, 地表下約 $50 \mathrm{~cm}$ の泥炭層, Ko-d テフラ(層厚 $15 \mathrm{~cm}$ ) が認められる が，その下位に重なる黒色腐植層中にイベント砂層は見られ ない. 野田生地域周辺の海浜砂は非常に淘汰が良い平均粒径 約 $1.7 \phi$ の粒子であった.

\section{森町鷲の木}

海岸線から内陸側約 $50 \mathrm{~m}$ に位置する国道 5 号線沿いの壁 面露頭において, 駒ヶ岳起源の噴出物が観察された (Fig. 11). その層序は下位から層厚 $1 \mathrm{~m}$ 以上の角閃石結晶に富む 再堆積性火山灰, 灰色の砂質シルトが間隙を充填する層厚約 $5 \mathrm{~cm}$ の砂層, 層厚約 $90 \mathrm{~cm}$ の Ko-d テフラが堆積してい る. 本礫層は最大長径十数 $\mathrm{cm}$ の扁平礫から構成されインブ リケーションが認められる. 碟層の堆積面は標高約 $11 \mathrm{~m}$ に 位置する. 
Table 2. Characteristics of the tsunami deposits in Uchiura Bay and on the Iburi coast. Tsunami identification after Goto et al. (2017).

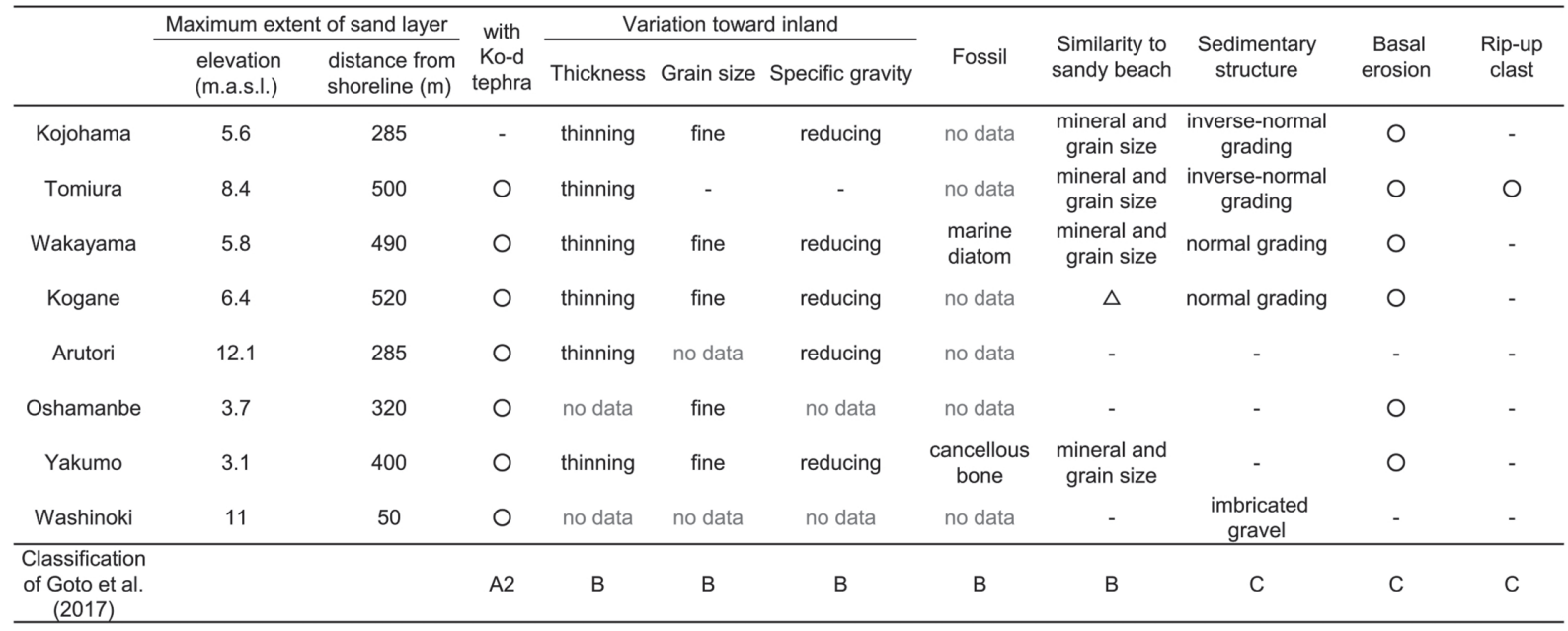

\section{イベント砂層の成因}

泥炭層などの定常的な堆積物に介在する「イベント堆積物」 が津波によるものか評価するため, 後藤ほか(2017)の手順 を参考に現世の堆積物との比較から津波堆積物の認定を試み た. 後藤ほか (2017)の認定フローでは, 現世の津波堆積物 と類似した堆積学的特徵を有すること $(\mathrm{C})$, 海水起源である こと (B), 歴史記録に対応すること(A2), 津波による堆積 が示唆されること $(\mathrm{A} 1)$ に根拠を分類し，このうち(B) は上 位分類基準である(A2) と(A1)の必要条件であるとしてい る. Table 2 では本調査地で確認されたイベント砂層の特徵 と後藤ほか (2017) の分類基準と関連する項目をまとめた.

海岸付近の地点で約 $4 \mathrm{~cm}$ 以上の層厚を持つ砂層は (虎杖 浜, 富浦) 逆級化と正級化のセットが認められ，この特徵は 現世の津波堆積物および大型水槽を用いた再現実験によって も観察される(Yoshii et al., 2017 など） (C).この堆積構 造はストーム堆積物にも見られるが(Morton et al., 2007), 後述するように本層の分布範囲の規模からストーム堆積物と は区別される. さらに虎杖浜と富浦で見られる本砂層の基底 面は明瞭である場合が多く, 偽礫が確認できる地点が存在す る $(\mathrm{C})$. 各測線において内陸に向けて薄層化・細粒化および 軽量化を示す $(\mathrm{B})$. 砂層の構成粒子は, 測線の海側に位置す る海浜や河口の砂に類似し, 海浜付近から供給されたと考え られる(B)，登別市富岸のイベント砂層は，約 $10 \%$ の汽〜 海水棲種の珪藻微化石を含んでおり (岡村ほか, 2012), 海水 起源を支持する $(\mathrm{B})$. 一方, 海域から運ばれる類似の堆積物 としてストーム堆積物が考えられるが, 重野・七山(2016) が渡島半島西岸において報告した 1959 年台風襲来に伴う砂 質イベント堆積物は，河口から上流へ最大 $70 \mathrm{~m}$ (標高約 $4 \mathrm{~m}$ )までの分布であり，その層厚は数十 $\mathrm{cm}$ から短距離の 範囲で薄層化する特徵を持つ. 本調査で明らかになつたイべ ント砂層は鷲の木を除く地域で海岸線から内陸に 300$500 \mathrm{~m}$ (標高 > $3 \mathrm{~m}$ ) まで追跡することが可能であり, 広範囲
にわたつて薄くシート状に分布しているため, ストーム堆積 物とは区別される (A1). 富浦以西の地点では, イベント砂 層の上位に Ko-d テフラが覆つており, 泥炭層の堆積速度が $0.1 \mathrm{~cm} /$ year (若山地域) という点を考慮すると火山噴火とほ ぼ同時期に堆積していると考えられ，歴史記録に残る 1640 年駒ヶ岳噴火にともなう山体崩壊による津波堆積物である可 能性が高い(A2).

\section{現世の津波堆積物との比較による浸水深の推定}

現世の津波調査によれば，津波堆積物が残される遡上限界 と浸水限界との間には乘離があり, 津波堆積物の存在する標 高は津波の「最低遡上高」を示し, 実際の遡上高はさらに高い と考えられる. そのため津波堆積物の分布標高を用いて津波 の規模を推定した場合，過小評価となる恐れがある. 2011 年の東北地方太平洋沖地震では多くのデー夕が収集され, 浸 水範囲と津波堆積物の分布の関係が検討された. Sawai et al. (2012) と宍倉ほか (2012) は, 緩傾斜の続く石巻平野にお ける砂質堆積物調査の結果, 堆積物の分布距離が浸水距離の 60\% 程度であったと報告している. このような乘離の要因 としては, 地形, 津波の流速と浸水深, 堆積物の粒径が考え られる(後藤・藤野, 2008). そこで Goto et al. (2014) は統 計的に砂質堆積物の分布末端から浸水深の推定を試み, 堆積 物の層厚分布から浸水深に対して約 $2 \%$ 分の厚さの堆積物 が残され, 浸水深 $1 \mathrm{~m}$ 未満では堆積物を残していないと報 告している. また, Namegaya and Satake(2014)は, 砂 質堆積物の分布限界における浸水深と流速を数值シミュレー ションし, 浸水深 $1 \mathrm{~m}$ 以上, 流速 $0.6 \mathrm{~m} / \mathrm{s}$ 以上になると推 定している. 以上の知見からは, 砂質堆積物が存在する地点 においては少なくとも $1 \mathrm{~m}$ の浸水深が示唆される. しかし ながら, 極細粒な砂を供給源に含む津波堆積物では浸水域と 堆積物分布域にほとんど乘離が見られない場合や, 粒度特性 や保存ポテンシャル, 引き波の影響からその乘離が大きくな る場合がある(後藤・藤野, 2008). そこで本論では, 津波堆 
積物の分布限界における浸水深 $1 \mathrm{~m}$ もしくはそれ以上が妥 当かを検討するため, 本調査地域と類似の地形条件を有する 青森県上北地域の 2011 年津波堆積物 (Nakamura et al., 2012; Koiwa et al., 2014) との比較を行った.

上北地域沖合の海底地形は水深 $100 \mathrm{~m}$ までの地形勾配が 0.6-1.0\%の緩傾斜からなり, 本調査地域の内浦湾から胆振 西部の浅海域が $0.5-0.7 \%$ を示すのと類似する. 陸上地形 について, 上北地域北部では 2-3 列の浜堤列 (2-3 m) が存 在し，その背後は低地とそれに続く防潮林に覆われた平地か らなり, 緩傾斜(0.5-1.5\%)の地形になっている (Nakamura et al., 2012). 南部については $6 \mathrm{~m}$ の堤防の背後に海岸林 に覆われた 1 列の浜堤列, 標高 3-4 m の海岸低地が続き, 海岸線から約 $300 \mathrm{~m}$ ほど内陸には段丘が存在する. 津波の 挙動については, 南部では津波が三度襲来し最大の波高を示 した第二波の夕が内陸へ越流した。 その波は河川を主な侵入 経路としその後続波が堤防や浜堤を超えて侵入し，戻り流は より低い地形に沿って排水した (Koiwa et al., 2014)。北部 では小河川などの低所から津波が侵入し，一部の浜堤を乗り 越えて侵食が起こつたとされており, 目立つた戻り流の痕跡 は見られなかった (Nakamura et al., 2012).

これらの地形条件と類似性を考慮し, 本調査地域を 4 つ に区分して比較検討した．A グループは八雲と長万部から なり, 浜堤の高まりが存在するもののその高まりと背後の低 地の高低差が顕著でなく, 低地が内陸に向かって非常に緩や かな傾斜をもつ地形である. B グループは富浦と黄金から なり, A グループ同様高低差が顕著でなく, 内陸に向かっ て $1-1.5 \%$ の傾斜を持つ地形. C グループは若山と虎杖浜 からなり, 海岸付近の高まりと背後の低地との差が顕著であ りさらに背後に高まりを有する地形. D グループは鷲ノ木 とアルトリ恋人浜からなり, 海浜に近接して急斜面を有する 地形である.

まず A グループは上北地域北部の Transect 1 (Nakamura et al., 2012) と比較を行つた. 津波の侵入経路は浜堤を切る チャネルや河川が存在することから，上北地域同様河口や低 地を侵入経路とした可能性が高い. Transect 1 における砂 質堆積物層厚は，浸水範囲の半分の距離から内陸では数 $\mathrm{cm}$ の薄層が連続して見られ，内陸に向けて 0.5-0.6 と軽量化傾向が見られる. Transect 1 の砂層分布標高と浸 水高との乘離は $1 \mathrm{~m}$ 程度と, なだらかな地形であることか ら乘離が小さい。公雲地域においては $2 \mathrm{~cm}$ 以下の薄層が内 陸側で連続的に見られ，内陸に向け $0.5 \phi$ の細粒化傾向が見 られた(Fig.10)。 八雲地域の砂質堆積物の粒度組成は2$2.5 \phi$ と上北北部の津波堆積物 (2-2.7 7 ) よりやや粗粒である が Transect 1 と類似した粒度組成と変化傾向をもつ. 本砂 層は Ko-d テフラに厚く覆われているため, 風化を免れてお り，平坦な地形であることから戻り流の影響も小さいと考え られる.これらの比較から八雲地域における砂層分布限界付 近の浸水深は Transect 1 と同程度と推定され， $1 \mathrm{~m}$ 程度で あったと考えられる. 長万部地域の津波堆積物については, Transect 1 と類似した粒度組成を持ち, 海浜砂に比べ砂質 堆積物の構成粒子は比重が小さな粒子群へと変化していた.
したがって Transect 1 と同様の乘離状態が推定され, 砂層 の分布限界における浸水深 $1 \mathrm{~m}$ 程度が妥当であると考えら れる.

B グループは低地と浜提に大きな標高差がなく $1 \%$ を超 える傾斜をもつ特徵から, 上北地域北部の測線 Transects 3 , 4 (Nakamura et al., 2012) と比較を行つた. Transects 3, 4 において砂層は数 $\mathrm{cm}$ で連続して分布しており, 内陸に向け 傾斜が大きくなつた地点で目立つた薄層化が見られる. 分布 限界付近における砂層中の有色鉱物の割合は海浜砂に比べ半 分以下と顕著な軽量化傾向を示す. Transects 3, 4 の分布標 高と浸水高との乘離は数十 $\mathrm{cm}$ から $2 \mathrm{~m}$ 程度と幅を持って いるが，これは変則的な勾配を有するためであると考えられ る. 富浦地域においては低地の続く測線において $3 \mathrm{~cm}$ 以上 の層厚であった砂層が, 傾斜の大きくなる TU-A において 著しく薄層化する. 砂層の構成粒子は内陸に向けて軽石など の比重の小さな粒子へと変化する明瞭な軽量化傾向を示す (Fig. 7). Nishimura et al. (2005)によれば，津波の遡上限 界付近では植物やゴミなどの漂着物が残され，津波によって 軽石を多く含む堆積物が運ばれた際, 津波の遡上限界に向け て砂質な堆積物から軽石が多くを占める堆積物に変化してい く様子が報告されている. そのため津波堆積物中の軽石粒子 は, 遡上限界付近まで運搬され再堆積したものと考えられ る. また, TU-A 地点において軽石粒子を除いた粒度のピー クは $2.1 \phi$ であり Transect 3 の分布限界の砂層 $(1.8-2.5 \phi)$ と類似する。富浦地域における測線上の層厚や粒子変化は Transects 3, 4 とよく類似しており, 比較地域の分布標高と 浸水高の乘離を考慮すると, 砂層の分布限界付近の浸水深は 1-2 $\mathrm{m}$ 程度が妥当であると考えられる. 黄金地域の津波堆 積物は傾斜の急な地点で急激な薄層化と細粒化, 顕著な軽量 化傾向を示し, 砂層の分布限界である KG-3 における平均 粒径は $2.5 \phi$ であり Transect 3 と類似の特徵を示す (Fig. 9). これらの堆積物の特徵や傾向は概ね Transects 3,4 と同様 の乘離を示すと考えられるが，デー夕数が少なく過小評価と なっている可能性がある. そのため黄金地域の調査結果が示 す砂層の分布限界は, 少なくとも 1-2 m 以上の浸水があっ た地点と考えられる.

Cグループは上北地域南部の測線 Transect D (Koiwa et al., 2014) に類似の地形条件を示し, 高さと奥行きのある高 まりを有し, 数百 $\mathrm{m}$ の低地が広がる. Transect D における 堆積層厚は, 周辺の段丘の高まりを越えると減少し, 段丘上 に堆積物が確認された地点の浸水深は 1-2 m であったこと が報告されている(Koiwa et al., 2014). 海浜砂の粒度は $1.75 \phi$ で内陸での津波堆積物は $2 \phi$ 程度まで細粒化傾向がみ られる. 若山地域では WY-8 から WY-11にかけて標高 $5 \mathrm{~m}$ の高まりで層厚が減少し, 標高 $9 \mathrm{~m}$ の段丘手前で砂層 が確認できなくなる (Fig. 8). 平均粒径 $2 \phi$ の粒子が主体と なっており上北南部と類似する. Ko-d テフラで覆われる地 点での砂層は擾乱・侵食を免れたと判断されるが，砂層の分 布限界付近は段丘に囲まれた閉鎖的な地形になっており戻り 流の影響が大きかつた可能性がある. しかし, 標高 $5 \mathrm{~m}$ の 高まりを越える地点での浸水深は少なくとも 1-2 m あった 


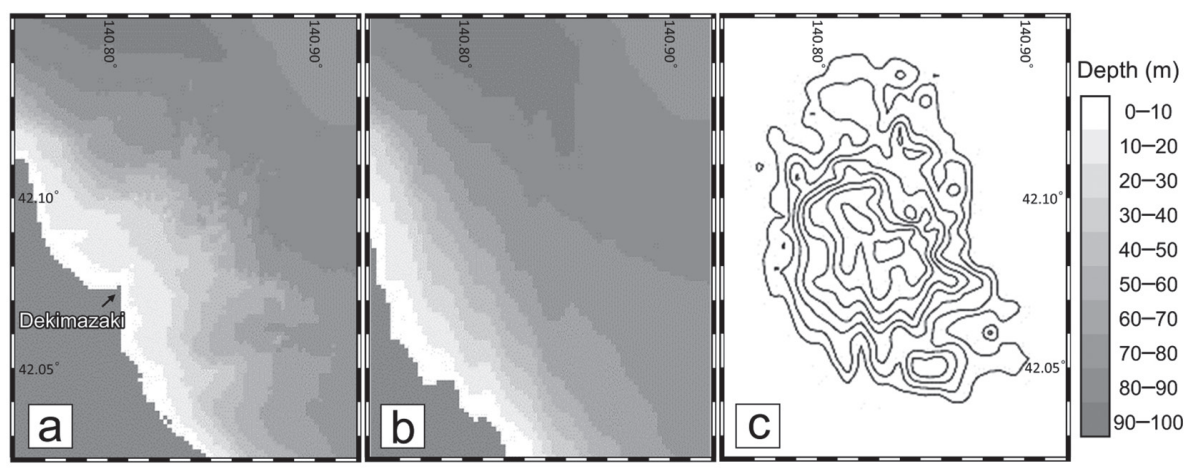

Fig. 12. (a) Current bathymetry in the vicinity of the debris avalanche derived from the 1640 Komagatake eruption (Fig. 1b). (b) Reconstructed bathymetry before the eruption. (c) Estimated distribution of the debris avalanche deposit. The contour interval in (a) and (b) is $5 \mathrm{~m}$.

と考えられ，最低でも 6-7 m の遡上高が推定される. 虎杖 浜地域における津波堆積物の分布限界は標高 $5.6 \mathrm{~m}$ の高ま り上である(Fig. 5). Us-b テフラに覆われた当時の浜堤上 に，より細粒な砂が堆積していたにも関わらず，分布限界付 近における津波堆積物の平均粒径は $0.5 \phi$ 以下と非常に粗粒 であったことから，津波の遡上高は砂層の分布より高かった 可能性がある. 分布限界である KJH-5 において，標高 5.6 $\mathrm{m}$ の高まりを乗り越えた津波は少なくとも 1-2 m を超える 浸水深をもつと推定される.

$\mathrm{D}$ グループは上北地域北部の測線 Transects $12,13(\mathrm{Na}-$ kamura et al., 2012) と類似する急崖地形であるが，津波の 浸水深と砂層との関係は乘離が大きいため比較は困難であ る. しかし，堆積物が残されている地点までは津波遡上が あったことは確実なので, 浸水深の推定は行わず, 砂層の分 布標高を最低遡上高として扱うことにする．アルトリ岬恋人 浜の津波堆積物は, Ko-d テフラに覆われて保存状態が良く, 構成粒子は軽石を主とする軽量化傾向を示しており，標高約 $12 \mathrm{~m}$ まで砂層が確認される. 本調査地域周辺では, 遺跡発 掘調査を中心に, 1640 年駒ヶ岳噴火津波の痕跡が調べられ ている. アルトリ岬北方有珠湾の対岸に位置する善光寺にお いては，歴史記録からこの地点の遡上高がおおよそ $8.5 \mathrm{~m}$ と求められている(つじ，1989)。西村・宮地(1998) は 7.3 $\mathrm{m}$ の高度まで津波堆積物を追跡している. 有珠湾付近に位 置する伊達市ポンマ遺跡においては, その分布が海岸から約 $290 \mathrm{~m}$ と限定的で, 現在の標高にして $5 \mathrm{~m}$ 以上の微高地に は堆積物が確認されない(添田ほか, 2011)。今回の調査結果 は, 従来のものに比べ津波堆積物の分布標高が数 $\mathrm{m}$ 高 $<$ なっているが, その要因は有珠湾内側と外側 (アルトリ岬恋 人浜) という位置関係に起因すると考えられ (Fig. 4e), アル トリ岬を含む善光寺岩屑なだれが作る流れ山地形が津波の勢 いを衰えさせ，津波の遡上に違いが生じた可能性がある．熟 の木については西村・宮地(1998)が，海食崖において 1640 年の津波堆積物を記載しており，その標高は $5.8 \mathrm{~m}$ と報告 している. 本調査で確認された碟質堆積物は $11 \mathrm{~m}$ とより高 い標高に存在するものの, 同時代の堆積物であることから同 一のイベントによる碟層であると考えられる. しかし, その
分布は海岸線に程近く, 内陸にかけて追跡することが困難で あることから参考值として扱う.

\section{AD1640 北海道駒ヶ岳噴火にともなう 津波の数值シミュレーション}

Nishimura and Satake(1993)は, $0.1 \mathrm{~km}^{3}$ の流入土砂量 で数值シミュレーションを実施したが, アルトリで $1 \mathrm{~m}$ 程 度と古文書記録から明らかにされている $8.5 \mathrm{~m}$ より低い波 高となつている. その原因の一つとして土砂流入量が過小に 見積もつていたことを挙げている. その後, Yamanaka and Tanioka(2017) は周辺地域の波高を説明できるように崩壊 前の山体を復元し, 海域への流入土砂量が最低でも $1.2 \mathrm{~km}^{3}$ 以上必要であると結論付けた. そこで, 本研究では津波堆積 物分布から推定された浸水高を, 数值シミュレーションを用 いて再現し, その津波規模と山体崩壊による流入土砂量の妥 当性を検討した。平石ほか(2001) は明和八重山津波につい て円弧地滑り法によって地滑り量を算出し, 土砂の移動によ る海底地盤変位と同等の水面変位が生じるものとして初期水 位分布を求めており, 津波痕跡を説明可能となるように倍率 をかけ試行計算を行っている. 本研究では, 平石ほか (2001) の方法を参考に, 海底地形から読夕取つた流入土砂の体積と 初期水位量を同等と夕なし計算を行つた. 初期水位量の検討 にあたっては Satake and Kato(2001)の手法に則り, 等深 線が滑らかに連続するよう崩壊前の地形を復元し, 現在の地 形との差を求めることで, 流入土砂の堆積層厚分布を推定し た (Fig. 12). この堆積層厚を隆起量として与えた場合の初 期水位分布を求め, その初期水位の最大值が $74 \mathrm{~m}$ から 122 $\mathrm{m}$ の範囲内で $12 \mathrm{~m}$ 毎の倍率計算を試みた. 津波伝播計算 について, 本来であれば土砂の流入過程を考慮し, これに よって発生する短波長成分に富んだ津波について非線形分散 波理論を用いて復元することが好ましいが，本研究では崩壊 土砂の層厚分布全体を水位上昇量の初期值としており, 水深 数十 $\mathrm{m}$ に対して波長が数 $\mathrm{km}$ となるため非線形長波理論を 用いることとした. 津波の初期水位と伝播の計算は高性能津 波計算コードJAGURS (Baba et al., 2015)を用いた. 地形 デー夕は中央防災会議資料の日本海溝 - 千島海溝周辺海溝型 


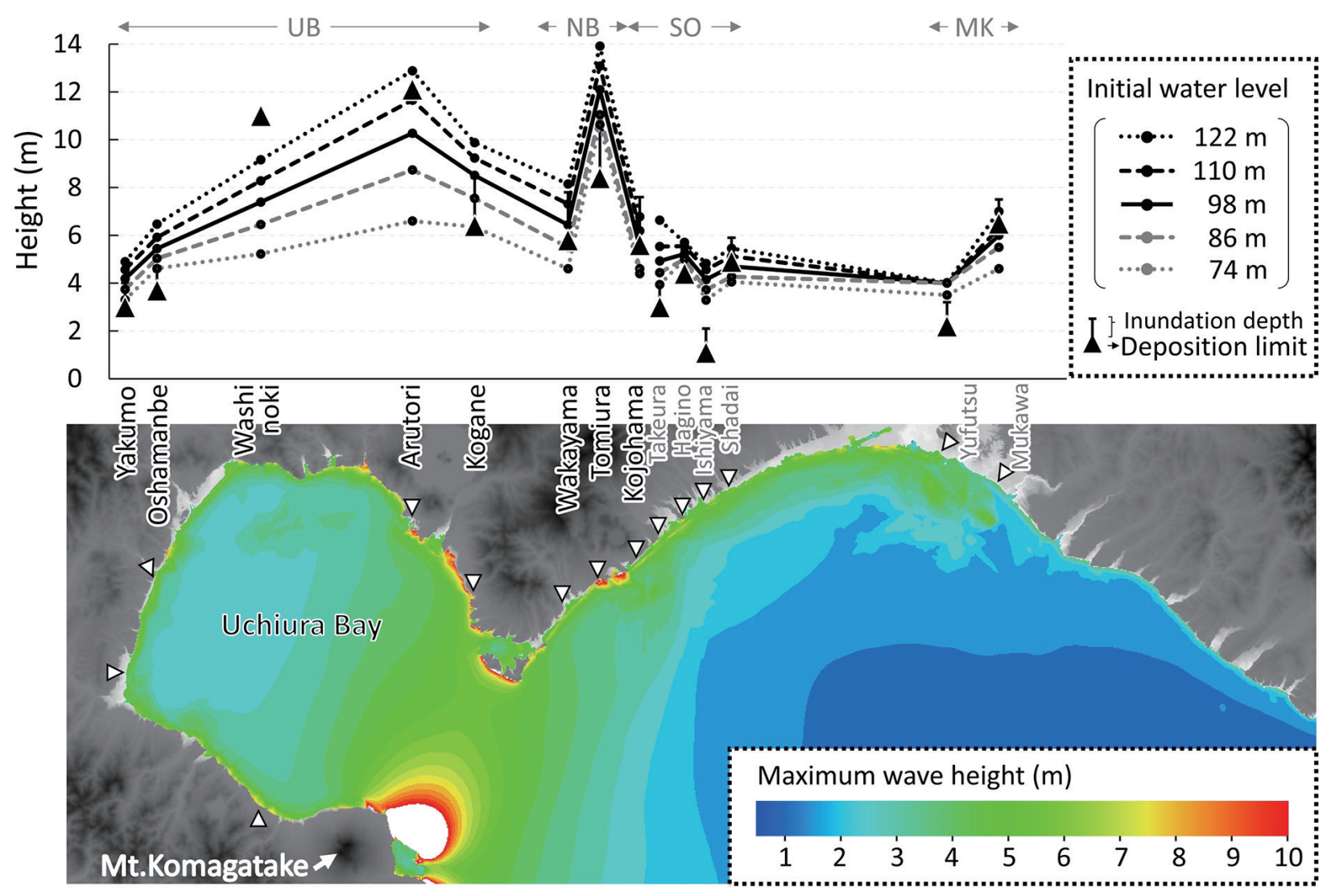

Fig. 13. Upper: comparison of computed run-up heights of the 1640 tsunami at five initial water-level conditions. Triangles show the elevations of the locations where tsunami deposits were found. Error bars show estimated inundation depth. The maximum distribution height of the tsunami deposit at Shiraoi was estimated from the data in Nakanishi et al. (2014); those of the deposits at Yufutsu and Mukawa from Takashimizu et al. (2007) and Okamura et al. (2012). Lower: maximum wave height distribution of the 1640 tsunami generated by the Komagatake eruption, using the numerical simulation of Baba et al. (2015) with an initial water level of $98 \mathrm{~m}$.

Table 3. Statistical comparison of estimated inundation height and numerically simulated inundation height under several initial water-level conditions. $K$ and $k$ values were calculated using the equation of Aida (1977). Abbreviations for tsunami deposit fields: UB, Washinoki, Yakumo, Oshamanbe, Arutori, Kogane; NB, Wakayama, Tomiura; SO, Kojohama, Takeura, Hagino, Ishiyama, Shadai; MK, Western Yufutsu, Eastern Yufutsu, Mukawa.

\begin{tabular}{|c|c|c|c|c|c|c|c|}
\hline \multirow{2}{*}{$\begin{array}{l}\text { Initial water } \\
\text { level }(\mathrm{m})\end{array}$} & \multicolumn{2}{|c|}{ UB - NB } & \multicolumn{2}{|c|}{ UB - SO } & \multicolumn{2}{|c|}{ UB - MK } & \multirow{2}{*}{$\begin{array}{l}\text { Volume of } \\
\text { debris }\left(\mathrm{km}^{3}\right)\end{array}$} \\
\hline & $K(n=7)$ & $\kappa(\mathrm{n}=7)$ & $K(n=12)$ & $\kappa(n=12)$ & $K(\mathrm{n}=15)$ & $k(\mathrm{n}=15)$ & \\
\hline 74 & 0.63 & 1.36 & 0.75 & 1.48 & 0.77 & 1.51 & 1.07 \\
\hline 86 & 0.78 & 1.49 & 0.86 & 1.50 & 0.88 & 1.49 & 1.29 \\
\hline 98 & 0.92 & 1.20 & 0.99 & 1.32 & 0.97 & 1.33 & 1.49 \\
\hline 110 & 1.06 & 1.54 & 1.11 & 1.50 & 1.06 & 1.47 & 1.70 \\
\hline 122 & 1.20 & 1.52 & 1.23 & 1.49 & 1.15 & 1.47 & 1.92 \\
\hline
\end{tabular}

地震に関する専門調査会のデータ(450-150-50 m メッシュ) を用いた．計算は 0.4 秒毎の波形変化を 100 分後まで行っ た.また，ライズタイムは土砂の流入継続時間を想定し, 120 秒とその前後 60 秒 $(60,180$ 秒) とした. この設定は岩 屑なだれの流動性の指標となる最大落差 $(\mathrm{H})$ と最大流走距離 (L)の比 (H/L 值)において, 吉本ほか (2003) が駒ヶ岳山体
崩壊と同程度の $\mathrm{H} / \mathrm{L}$ 值を持つとした 1792 年の眉山山体崩 壊の数值シミュレーション結果(飯塚ほか, 2017)を基にし た. 潮位変化については, Yamanaka and Tanioka(2017) が指摘しているように, 変化量が小さいため考慮していな い. マニングの粗度係数は陸海ともに $0.025 \mathrm{~m}^{-1 / 3} \mathrm{~s}$ とした. 津波堆積物の分布標高各パラメータのシミュレーションに よって得られた津波遡上高を比較するため, 各グループで推 定された最大浸水高を用いて相田(1977)の方法を用いて両 者の比の幾何平均值 $K$ と幾何標準偏差 $k$ を求めた (Table 3). $K$ は計算值が実測值の何倍であるかの指標となり, $k$ は 1 に 近いほど実測值と計算值のバラつきが小さいこと示す.

Fig. 13 は, 各初期水位条件における各地点の最大遡上高 の計算結果と以下の検討から最適モデルと考えられる初期水 位条件 $98 \mathrm{~m}$ の場合の最大波高分布を示す．比較のために, 本調査地域より東側に位置する白老からむかわ(高清水ほか, 2007; 岡村ほか, 2012; 中西ほか, 2014)で報告されている 津波堆積物の分布標高(浸水深は+ $1 \mathrm{~m}$ と仮定)を示す. Fig. 13 によると, アルトリ, 富浦地域ではアルトリ岬や蘭 法華岬 (Line TUの東側 : Fig. 4b) といつた張り出した地形 に近接するため, 局所的に高い遡上高を示している. 鷲の木 


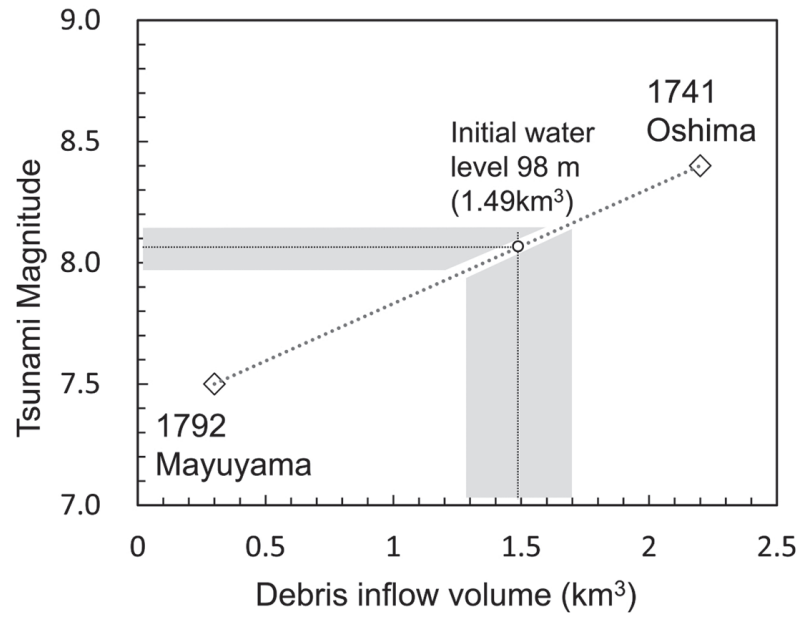

Fig. 14. Tsunami magnitude (Mt) vs. volume of debris avalanche deposit. Data for the 1741 Oshima-Oshima event are taken from Ioki et al. (2017); data for the $1792 \mathrm{Ma}$ yuyama event are from Yamanaka and Tanioka (2017).

やアルトリ地域では津波堆積物の分布標高に比べ計算結果の 遡上高が低くなる傾向が見られるが，これはこの地域が急崖 を成す複雑な地形であるため, 地形デー夕の解像度が足りて いないことや，分散性を考慮していないために再現性が低く なっていることが影響している可能性がある. Ko-d テフラ に覆われた津波堆積物が確認された地点で, 砂層分布限界ま で浸水が認められるのは初期水位 $86 \mathrm{~m}$ 以上であったため, これ未満の条件は過小評価であると考えられる. 一方, 初期 水位 $122 \mathrm{~m}$ の計算值では粒度組成や層厚変化から堆積物の 分布限界をよく示していると考えられる若山地域や富浦地域 を含めて多くの地域で推定值を越えている. これらの地域で は沿岸域に道路や堤防が造成されていることから津波発生当 時より浸水し難い地形であると考えられるが, 推定浸水高を 大きく超える計算結果となっているため，このようなシミュ レーション值は調査結果にそぐわない。，八雲と若山地域は野 外調査で網羅的に堆積物の分布が明らかになっており，上北 地域との類似性も高いため, 浸水高について信頼度が高い. 両地域で推定された浸水高を満たしているのは初期水位 98 $\mathrm{m}$ および $110 \mathrm{~m}$ の条件であった. 全体として幾何平均值 $K$ においてほぼ等倍で満たし, 幾何標準偏差 $k$ の值から最も バラつきが小さくなる条件は初期水位 $98 \mathrm{~m}$ の条件となつ た. 土砂の流入継続時間については，短時間であるほどわず かに高い波高を示すが, 60 秒と 120 秒との差は最大で士 $1 \mathrm{~m}$ (アルトリ), 平均して $0.7 \mathrm{~m}$ の違いであり, この差は 地域間の実際の遡上高の違いを生み出す要因にはならないと 考えられる．なお，初期水位条件 $86 \mathrm{~m} ， 98 \mathrm{~m}, 110 \mathrm{~m}$ に おける海底地盤変位 (土砂流入量) はそれぞれ $1.29,1.49$, $1.70 \mathrm{~km}^{3}$ であり (Table 3), Yamanaka and Tanioka(2017) の推定值と調和的である. しかし, 本研究では山体崩壊の過 程や分散性が考慮されていないため，より精度の高い土砂流 入量の評価には短周期波を復元した波源モデルの構築が必要 である。
白老地域におけるシミュレーション結果は, $98 \mathrm{~m}$ 以上の 初期水位で津波堆積物の分布域まで浸水が及ぶ結果となつ た.しかし，白老地域では 50-100 cm に達する厚い Us-b テフラが津波堆積物を覆っており (中西ほか, 2014), 当時の 地形は現在より最大 $1 \mathrm{~m}$ 低かったと考えられる. したがっ て, 初期水位条件 $86 \mathrm{~m}$ の場合でも砂層の分布範囲まで浸水 があった可能性がある. 内浦湾から白老地域の幾何平均 $K$ と幾何標準偏差 $k$ の值は初期水位 $98 \mathrm{~m}$ の条件で最もばらつ きが小さい $(K=0.99, k=1.32)$. 一方, 白老地域より東 側に位置する勇払からむかわにかけては白老地域より高い最 大津波水位 (初期水位 $98 \mathrm{~m}$ で 6-7 m 程度) を示す。この原 因は，沿岸を沿うように伝わつた波が勇払からむかわにかけ ての凹形状をなす地形条件によって波高が高くなったためと 考えられる. しかし，これらの地域では数值シミュレーショ ンによる最大遡上高が津波堆積物の分布標高を越えているも のの，砂層の分布範囲まで浸水していない．この原因の一つ としては, 白老地域と同様, 厚いテフラ層が堆積しているた め, 現在の地形条件で行ったシミュレーションが当時の遡上 高を再現できていないことが考えられる。

\section{津波マグニチュードの推定}

津波の波高は経験的に波源から離れるにしたがい小さくな るとされている. この特性から津波の最大全振幅を用いて津 波の大きさを求める津波マグニチュード $(\mathrm{Mt})$ は, 以下のよ うに定義される(Abe, 1981).

$$
\mathrm{Mt}=\log \mathrm{H} 2+\log \Delta+5.55
$$

ここで, $\mathrm{H} 2$ は検潮儀で観測された津波の最大全振幅 $(\mathrm{m})$, $\Delta$ は震央から観測点までの海洋上の最短距離 $(\mathrm{km})$ を表し, $\mathrm{Mt}$ は $\mathrm{Mw}$ に平均として同じ值となるよう定義されている. $\mathrm{H} 2$ は実測高との統計的検討から各調査区間 $(20-40 \mathrm{~km})$ で の最大の実測高 (最大浸水遡上高) と近似できるとされている (Kajiura, 1983). 震源断層を持つ地震性の津波では, 断層 面積を円形に置き換えた領域の半径 $\left(\mathrm{r}_{0}\right)$ が $\Delta \leqq \mathrm{r}_{0}$ の関係と なった場合，津波波高の最大值は一定になる(Abe, 1981). しかし, 1640 年駒ヶ岳噴火の場合, 山体崩壊の堆積物の分 布は半径数 $\mathrm{km}$ であり, 数十 $\mathrm{km}$ 離れた本調査地域につい ては，この点を考慮する必要はない. 山体崩壊にともなう津 波の例として，阿部(1999) は，1741 年渡島大島津波, 1792 年島原眉山津波について, 古文書の記載から求めた遡 上高を用いて，それぞれ Mt 8.4, Mt 7.5 と推定している. Yamanaka and Tanioka (2017)の数值シミュレーションで は, 1640 年の駒ヶ岳噴火の山体崩壊量は $1.20 \mathrm{~km}^{3}$ 以上と 見積もられており, 本研究では 1.29-1.70 $\mathrm{km}^{3}$ と推定した. Fig. 14 は，それぞれの津波の土砂流入量と Mt の関係を示 してある. 渡島大島と眉山が示す相関式から, 北海道駒ヶ岳 は Mt 7.9-8.2 程度と推定される.

Fig. 15 には, 駒ヶ岳山体崩壊物流入地点 (出来澗崎) から の距離と各地点で確認された津波堆積物の分布標高, および 数值シミュレーションによって算出された最大遡上高をプ ロットした，本図には津波規模を推定するため，Mw 7.8- 

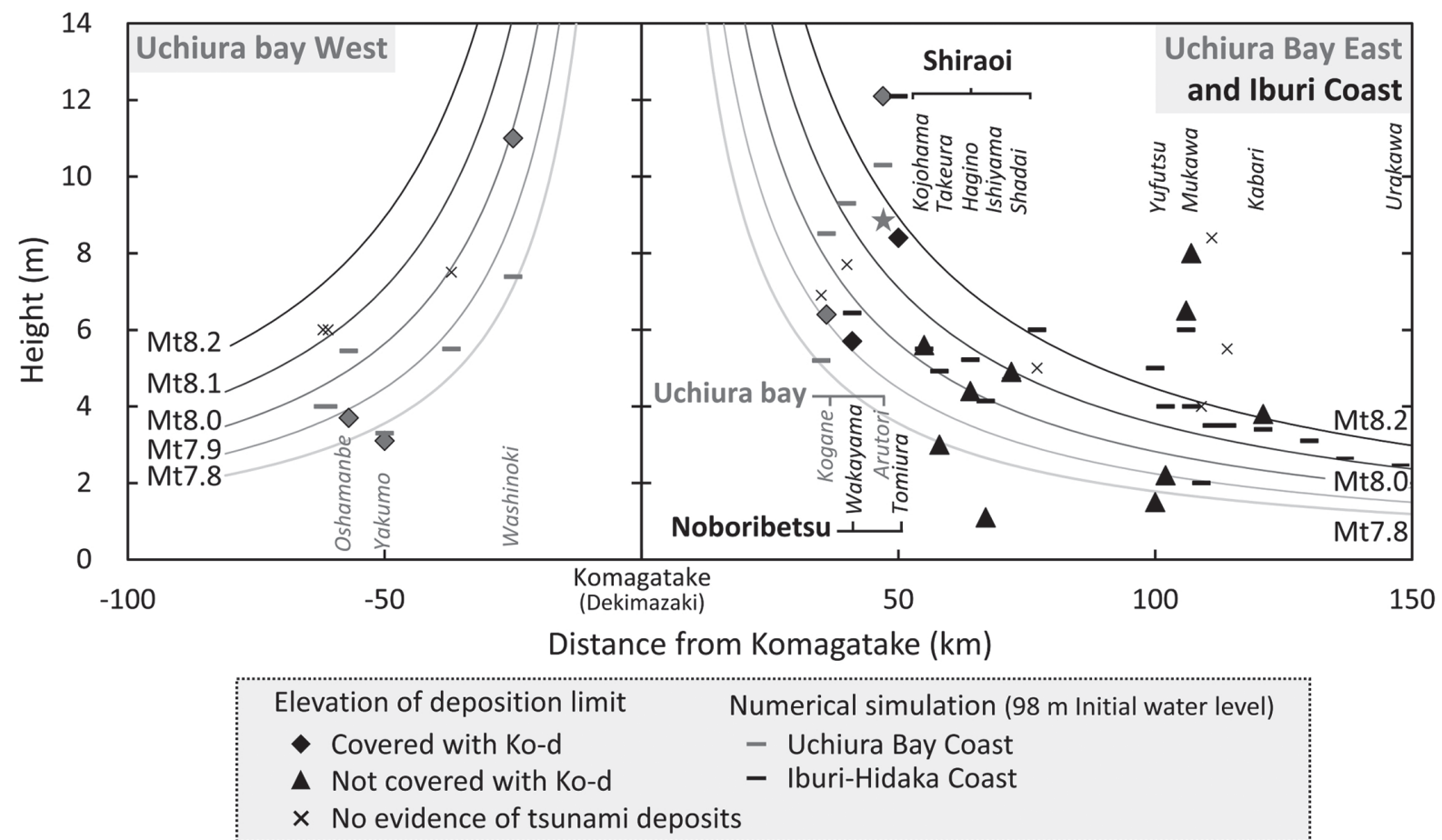

Fig. 15. The tsunami deposit elevations and the Baba et al. (2015) numerical simulation for the 1640 Komagatake eruption vs. distances from the source of the tsunami generated by the Komagatake eruption. Empirically calculated distribution patterns of the wave heights of 7.8 to $8.2 \mathrm{Mt}$ events (Abe, 1981) are shown for comparison. The maximum distribution height of tsunami deposits at Shiraoi was estimated from the data in Nakanishi et al. (2014), those of deposits at Yufutsu and Mukawa from Takashimizu et al. (2007) and Okamura et al. (2012), and that of deposits at Kabari from Takashimizu et al. (2017). The inundation height at Zenko-ji (star) was obtained from Tsuji (1989).

8.2 の地震が起きた場合に震央からの距離に応じてどの程度 の波高(最大浸水遡上高)が推定されるかを数式(1)から求め て表わした．また，周辺地域の津波堆積物分布と比較を行う ために，白老から賀張地域における津波堆積物の分布標高 (高清水ほか, 2007; 岡村ほか, 2012; 中西ほか, 2014; 高清 水ほか, 2017)をプロットした.

Fig. 15 から, 津波堆積物の分布標高およびシミュレー ションによる波高は, いずれも駒ヶ岳から遠ざかるにつれて 減少傾向が読夕取れる.土砂が流入したとされている駒ヶ岳 の東方向(Fig. 15 の横軸正の值)では津波堆積物の分布標高 およびシミュレーション值の多くが, Mtから求められる津 波波高 (最大浸水高・遡上高) の Mt 7.9-8.2 のレンジに含ま れており，駒ヶ岳を波源とした場合，同規模の津波で説明す ることが可能である. また, この $\mathrm{Mt}$ の值は土砂流入量と Mt の相関図 (Fig. 14) から求められる值 $\left(1.49 \mathrm{~km}^{3}\right.$ のとき Mt 8.0-8.1) とも矛盾しない. ただし，アルトリ岬や富浦は Mt 8.2 をやや超える値となっているが, これは張り出した 地形の影響で局所的に高くなったためと考えられる．白老地 域の石山・竹浦では堆積物の分布標高が $3 \mathrm{~m}$ 以下と小さい 值となっているが，これは地形が非常に平坦なためである (中西ほか, 2014). 白老から日高に至る地域においても, 駒ヶ岳を波源とした Mt 8.2 以下の津波で多くの津波堆積物 分布標高を説明可能であるが, むかわ地域については数值シ ミュレーションと Mt 8.2 の津波規模より高い分布標高を示
す結果となった. 一方, 土砂流入方向の背後に位置する内浦 湾西部 (Fig. 15 の横軸負の值) では津波伝播が山体に遮られ るため, おおよそ Mt 7.8-8.0 とやや小規模になったと考え られる。

\section{北海道太平洋沿岸西部における 17 世紀津波の波源の検討}

本地域を含む胆振から日高地域の 17 世紀における津波の 波源としては, 1640 年駒ヶ岳山体崩壊による津波の他に, 千島海溝を震源とするプレート境界型地震, あるいは AD1611 年の慶長津波が挙げられる(高清水, 2017)。本調 査では虎杖浜を除く各測線において, 津波堆積物を直接覆う Ko-d テフラが確認された。 これらの地域では津波堆積物が 挟在する泥炭層は比較的未分解であり, その堆積速度が 0.1 $\mathrm{cm} /$ year 程度であると仮定すると, 数年間で明膫な泥炭層 が堆積し識別できるはずである．したがつて本地域の層序を 考慮すると, 津波と駒ヶ岳噴火はほぼ同時とみなしてよいで あろう，虎杖浜を含む白老地域は, Ko-d テフラは確認でき ないが, 津波堆積物の分布標高は数值シミュレーション結果 や Mt 7.9-8.2 の津波規模で説明可能であり, 1640 年駒ヶ 岳噴火を波源とした可能性が高い.

一方, 胆振海岸東方の勇払から賀張地域にかけての津波堆 積物の分布標高は, 駒ヶ岳噴火を波源とした津波規模や数値 シミュレーション結果より有意に高い結果となっている (Fig. 15)。 むかわ地域の津波堆積物の最大分布標高は $8 \mathrm{~m}$ 
を超えており(高清水ほか, 2007)，駒ヶ岳山体崩壊の津波規 模から推定される遡上高とは大きく異なる. しかし, 数值シ ミュレーションが示すように，勇払からむかわ地域は海岸線 の方向が駒ヶ岳の山体崩壊の方向と直角に面しており，局所 的に最大津波水位が高くなる傾向を示す (Fig. 13). さらに, 津波発生当時は厚いテフラ層(Us-b) が存在しない低地で あったことを考慮すると, 胆振東部で見つかつた津波堆積物 も駒ヶ岳噴火によって残された可能性は十分考えられる。 ま た，むかわ地域で高い遡上高を示す場所は大きな河川が存在 しており, 津波発生当時とは地形が異なっているだろう。こ れらの地域については, 今後, 17 世紀以降の火山灰降灰以 前の地形, 河川流路や汀線の復元を行い，より正確な浸水規 模の評価を行う必要がある.

北海道東部におけるプレート境界型地震の津波堆積物調査 では, 北海道東部太平洋沿岸における 17 世紀の津波痕跡の ほか，数十から数百年おきに繰り返し起きた津波の痕跡が報 告されている (Sawai et al., 2009など)。しかし，内浦湾沿 岸から胆振海岸西部においては, B-Tm テフラより下位の 泥炭層中に津波痕跡を見出すことができなかった. 本調查地 域周辺の完新世における地殼変動は十分解明されていない が, 海退後の 2000 年前以降において, 泥炭湿地などの地形 的条件は大きく変化していないと推定される. したがって, 本地域周辺においては，17 世紀の津波を除くと，少なくと も過去千数百年の間に数百年おきに繰り返すような大規模な 津波災害が生じた可能性は低いと考えられる。 今後, 胆振海 岸東部から日高海岸にいたる地域の津波堆積物の検討を行 い，数百年間隔のプレート境界型津波の規模を推定し, 津波 の繰り返し性や波源域を明らかにする必要がある.

\section{ま と め}

内浦湾沿岸から胆振海岸西部にいたる 8 地域において, 1663 年有珠山噴火テフラ (Us-b) を鍵層としてその下位にイ ベント堆積物の存在を明らかにした。これらのイベント堆積 物の粒度・鉱物組成は, 現在の海浜周辺の砂と類似し, 内陸 に向け薄層化・細粒化・軽量化する特徵を示し, 海側から供 給されたことがわかった. 内浦湾沿岸から胆振海岸登別市富 浦までのイベント堆積物は, 1640 年の駒ヶ岳噴火テフラ (Ko-d) に覆われていることから, 1640 年の駒ヶ岳噴火に よる山体崩壊にともなう津波堆積物と判断される. その堆積 物は最大十数 $\mathrm{m}$ の分布を示し, これまで西村・宮地 (1998) によって報告されたものより大規模な津波であった．各地点 の津波堆積物の分布標高を基に，堆積物の層相や地形条件を 考慮し, 現世の津波堆積物調查結果との比較から浸水深 1 $\mathrm{m}$ 程度が妥当であるか検討した. さらにこれらが，1640 年 北海道駒ヶ岳噴火にともなう津波で説明可能かどうかを検証 するために, 山体崩壊による津波発生の数値シミュレーショ ンを用いて検討したところ, $1.20 \mathrm{~km}^{3}$ を超える崩壊物流入 量によってこれらの浸水が再現できた。この津波の規模はお よそ Mt 7.9-8.2 と見積もられ, 内浦湾沿岸から胆振海岸白 老地域に分布する堆積物を 1640 年の駒ヶ岳噴火津波で説明 可能であることがわかった.
謝辞

本研究を進めるにあたり, 西村裕一氏 (北海道大学) ・高清 水康博氏(新潟大学) ・佐竹健治氏 (東京大学)には貴重なご助 言と情報提供をいただいた. 数值シミュレーションのプログ ラム立ち上げについて, 馬場俊孝氏(徳島大学)および井上祥 史氏 (北海道教育大学札幌)からご助言をいただき, 山中悠資 氏(東京大学)には流入土砂量の評価法についてご教示いただ いた. 井島行夫氏ならびに前田寿嗣氏には火山灰の屈折率測 定についてご指導いただいた，現地調査においては，長谷川 大輔氏と北林修一氏のご協力をいただいた。担当編集委員の 藤野滋弘氏 (筑波大学) と二名の匿名査読者のご指摘によって 本稿は大幅に改善された. 以上の方々に心より感謝申し上げ ます。本研究の一部には深田野外調査助成を使用した.

\section{文献}

Abe, K., 1981, Physical size of tsunamigenic earthquakes of the northwestern Pacific. Phys. Earth Planet. Inter., 27, 194205.

阿部勝征, 1999, 遡上高を用いた津波マグニチュード Mt の決定一歴 史津波への応用一。地震第 2輯, 52, 369-377. [Abe, K., 1999, Quantification of historical tsunamis by the Mt Scale. $J$. Seismol. Soc. Japan, 2nd Ser. 52, 369-377.]

相田 勇, 1977, 三陸沖の古い津波シミュレーション. 東京大學地震 研究所彙報, 52, 71-101. [Aida, I., 1977, Simulations of large tsunamis occurring in the past off the coast of the Sanriku district. Bull. Earthquake Res. Inst., Univ. Tokyo, 52, 71101.]

Baba, T., Takahashi, N., Kaneda, Y., Ando, K., Matsuoka, D. and Kato, T., 2015, Parallel implementation of dispersive tsunami wave modeling with a nesting algorithm for the 2011 Tohoku Tsunami. Pure Appl. Geophys., 172, 34553472.

Folk, R. L. and Ward, W. C., 1957, Brozos River Bar: A study in the significance of grain size parameters. J. Sediment. Petrol., 27, 3-26.

後藤和久・藤野滋弘, 2008, 2004 年インド洋大津波後の津波堆積物 研究の課題と展望. 地質雑, 114, 599-617. [Goto, K. and Fujino, S., 2008, Problems and perspectives of the tsunami deposits after the 2004 Indian Ocean tsunami. J. Geol. Soc. Japan, 114, 599-617.]

Goto, K., Hashimoto, K., Sugawara, D., Yanagisawa, H. and Abe, T., 2014, Spatial thickness variability of the 2011 Tohoku-oki tsunami deposits along the coastline of Sendai Bay. Mar. Geol., 358, 38-48.

後藤和久 - 菅原大助・西村裕一 - 小松原純子 - 藤野滋弘 - 澤井祐紀 高清水康博, 2017, 津波堆積物の認定手順. 津波工学研究報告, 33, 45-54. [Goto, K., Sugawara, D., Nishimura, Y., Komatsubara, J., Fujino, S., Sawai, Y. and Takashimizu, Y., 2017, Identification procedure of tsunami deposit. Res. Rep. Tsunami Eng., 33., 45-54.]

平石哲也・柴木秀之・原 信彦, 2001, 円弧滑り法を利用した地滑り 津波波源による明和八重山地震津波の再現. 海岸工学論文集, 48, 351-355. [Hiraishi, T., Shibaki, H., Hara, N., 2001, Numerical simulation of Meiwa-Yaeyama earthquake tsunami in landslide model with circular rupture. Proc. Coast. Eng., 48, 351-355.]

胆振団体研究会, 1990 , クッタラ火山の火砕堆積物一支笏火山のテフ ラの層序の検討とテフロクロノロジー-. 地球科学, 44, 95112. [Iburi Collaborative Research Group, 1990, Pyroclastic deposits of Kuttara volcano, southwestern Hokkaido, Japan. Earth Sci. (Chikyu Kagaku), 44, 95-112.]

飯塚敬一・酒井信介・石原史隆・木村達人 $\cdot$ 谷 智之 $\cdot$ 大島貴充 $\cdot 山$ 
下恭平, 2017 , 土砂崩壊モデルと二層流モデルを用いた 1792 年 眉山崩壊による津波の再現シミュレーション. 土木学会論文 $2 \mathrm{~B}$ (海岸工学), 73, I_313-318. [Iizuka, K., Sakai, S., Ishihara, F., Kimura, T., Tani, T., Oshima, T. and Yamashita, K., 2017, Numerical simulation of 1792 tsunami by Unzen-Mayuyama collapse using landslide model and two layer model J. Japan Soc. Civil Eng., Ser. B2 (Coastal Eng.), 73, I_313318.]

伊尾木圭衣 - 柳澤英明 - 谷岡勇市郎 - 川上源太郎 - 加瀬善洋 - 仁科 健二...... 石丸 聡, 2017, 1741 年渡島大島での山体崩壊と津波遡 上域の数値シミュレーションによる再現. 地球惑星科学連合大 会 2017 大会予稿集, HDS16-11. [Ioki, K., Yanagisawa H., Tanioka Y., Kawakami G., Kase Y., Nishina K.,...Ishimaru S., 2017, Tsunami and landslide model due to the 1741 Oshima-Oshima eruption in Hokkaido, Japan. JpGU. Meet. 2017, Abstr., HDS16-11.]

地震調査研究推進本部地震調査委員会編, 2017, 千島海溝沿いの地震 活動の長期評価 (第三版)。130p. [Earthquake Research Committee, Headquarters for Earthquake Research Promotion, Prime Minister's Office, Government of Japan, ed., 2017, Long term Evaluation of Earthquake Activity along the Kuril Trench (Third Ed.). 130p.]

Kajiura, K., 1983, Some statistics related to observed tsunami heights along the coast of Japan. In Iida, K. and Iwasaki, T., eds., Tsunamis: Their Science and Engineering. Terra Sci. Pub., Tokyo,131-145.

勝井義雄・横山 泉・藤田隆男・江原幸雄, 1975, 駒ヶ岳. 北海道防 災会議. 194p. [Katsui Y., Yokoyama, I., Fujita, T. and Ehara, Y., 1975, Komagatake report of the volcanoes in Hokkaido. Sapporo Committee for Prevention of the Natural Disaster of Hokkaido. 194p.]

Koiwa, N., Kasai, M., Kataoka, S. and Isono, T., 2014, Examination of relation with tsunami behavior reconstructed by on-site sequence photographs, topography, and sedimentary deposits from the Tohoku-oki tsunami on the Kamikita plain, Japan. Mar. Geol., 358, 107-119.

Morton, A. R., Gelfenbaum, G. and Jaffe, E. B., 2007, Physical criteria for distinguishing sandy tsunami and storm deposits using modern examples. Sediment. Geol., 200, 184-207.

Nakamura, Y., 2016, Stratigraphy, distribution, and petrographic properties of Holocene tephras in Hokkaido, northern Japan. Quatern. Int., 18, 52-62.

Nakamura, Y., Nishimura, Y. and Putra, P. S., 2012, Local variation of inundation, sedimentary characteristics, and mineral assemblages of the 2011 Tohoku-oki tsunami on the Misawa coast, Aomori, Japan. Sediment. Geol., 282, 216-227.

中西 諒・長谷川大輔・岡村 聡, 2018, 高密度ボーリング調査と微地 形から明らかにする歴史津波の挙動と堆積物の特徵〜北海道登 別市における 17 世紀津波堆積物〜。日本堆積学会 2018 年秋田 大会講演予稿集, 63-64. [Nakanishi, R., Hasegawa, D. and Okamura, S., 2018, 17th century tsunami behavior in Noboribetsu, western Pacific coast, Hokkaido: Depositional and topographical constraints. 2018 Sediment. Soc. Japan, Abstr., 63-64.]

中西 諒 ・ 岡村 聡 - 高清水康博・嵯峨山 積 ・ 仁科健二, 2014, 北海道 胆振海岸, 白老地域に見られる 17 世紀津波堆積物の分布と波源 の検討. 地団研専報, 60, 169-178. [Nakanishi, R., Okamura, S., Takashimizu, Y., Sagayama, T. and Nishina, K., 2014, Distribution and origin of the 17th century tsunami deposit in Shiraoi, western Iburi coast, Hokkaido, northern Japan. Monog. Assoc. Geol. Collab. Japan, 60, 169-178.]

Namegaya, Y. and Satake, K., 2014, Reexamination of the AD 869 Jogan earthquake size from tsunami deposit distribution, simulated flow depth, and velocity. Geophys. Res. Lett., 41, 2297-2303.

西村裕一・宮地直道, 1998, 駒ヶ岳噴火津波 (1640 年)の波高分布に ついて. 火山, 43, 239-242. [Nishimura, Y. and Miyaji, N., 1998, On height distribution of tsunami caused by the 1640 eruption of Hokkaido-Komagatake, Northern Japan. Bull. Volcanol. Soc. Japan, 43, 239-242.]

Nishimura, Y., Nakagawa, M., Kuduon, J. and Wukawa, J., 2005, Timing and scale of tsunamis caused by the $1994 \mathrm{Ra}-$ baul eruption, East New Britain, Papua New Guinea. In satake, K., eds., Tsunami: Case Studies and Recent Developments, Springer, 43-56.

Nishimura Y. and Satake, K., 1993, Numerical computations of tsunamis from the past and future eruptions of Komagatake Volcano, Hokkaido, Japan. Proc. IUGG/IOC Int. Tsunami Symp., 573-583.

岡村 聡 - 伊藤和矢 - 永井 潤 - 桑谷大祐 - 三浦祐紀 - 角井貴博......嵯 峨山 積, 2012, 北海道胆振海岸に分布する 17 世紀津波堆積物. 苫小牧市博物館館報, 9, 15-24. [Okamura, S., Ito, K., Nagai, J., Kuwatani, D., Miura, H., Kakui, T.,...Sagayama, T., 2012, A 17th-century tsunami deposit distributed in the Iburi coast, Hokkaido, Japan. Tomakomai City Mus. Kanpo, 9, 15-24.]

Satake, K. and Kato, Y., 2001, The 1741 Oshima-Oshima eruption extent and volume of submarine debris avalanche. Geophy. Res. Lett., 28, 427-430.

Sawai, Y., Kamataki, T., Shishikura, M., Nasu, H., Okamura, Y., Satake, K.,...Aung T. T., 2009, Aperiodic recurrence of geologically recorded tsunamis during the past 5500 years in eastern Hokkaido, Japan. J. Geophys. Res., 114, B01319.

Sawai, Y., Namegaya, Y., Okamura, Y., Satake, K. and Shishikura, M., 2012, Challenges of anticipating the 2011 Tohoku earthquake and tsunami using coastal geology. Geophys. Res. Lett., 39, L21309.

重野聖之・七山 太, 2016, 台風来襲時の高波と高潮の相互作用によっ て沿岸低地に生じた小規模な砂質イベント堆積物の堆積過程一 1959 年 9 月 18 日午前 9 時から 19 日午前 1 時の間に渡島半島 西岸平浜海岸低地において生じた事例 -. 地学雑, 125, 747762. [Shigeno, K. and Nanayama, F., 2016, Sedimentary process of a small sandy event deposit due to a storm surge and storm waves generated by a typhoon: an example from the Hirahama coastal lowland along the western coast of the Oshima Peninsula between 09: 00 September 18 and 01:00 September 19, 1959. J. Geogr (Chigaku Zasshi)., 125, 747762.]

宍倉正展・藤原 治・澤井祐紀・行谷佑一 - 谷川晃一郎, 2012, 2011 年東北地方太平洋沖地震により津波堆積物の仙台 - 石巻平野に おける分布限界. 活断層・古地震研究報告, 12, 45-61. [Shishikura, M., Fujiwara, O., Sawai Y., Namegaya, Y. and Tanigawa, K., 2012, Inland-limit of the tsunami deposit associated with the 2011 Off-Tohoku Earthquake in the Sendai and Ishinomaki Plains, northeastern Japan. Ann. Rep. Active Fault and Paleoearthquake Res., 12, 45-61.]

添田雄二 - 山田悟朗 - 鈴木明彦 - 都郷義寛 - 池田陽香 - 渡辺 風....... 赤松守雄, 2011, アイヌ文化期における小水期とその影響に関す る研究一伊達市ポンマ遺跡および千歳市末広 2 遺跡での調査報 告一, 北海道開拓記念館研究紀要, 39, 73-90. [Soeda, Y., Yamada, G., Suzuki, A., Togoh, Y., Ikeda, H., Watanabe, T.,...Akamatsu, M., 2011, Study on the Little Ice Age during the ainu Culture Period and its Impact-Research Report at the Ponma Site in Date City and Suehiro2 Site in Chitose City -. Bull. Hist. Mus. Hokkaido, 39, 73-90.]

曽屋龍典・勝井義雄 - 新井田清信 - 堺 幾久子・東宮昭彦, 2007, 有 珠火山地質図 (第2 版) 1: 25,000. 地質調査総合センター. [Soya, T., Katsui, Y., Niida, K., Sakai, K. and Tomiya, A., 2007, Geological Map of Usu Volcano (2nd Ed.), Scale 1: 25,000. Geol. Surv. Japan, AIST.]

高清水康博, 2017, 北海道太平洋岸の津波堆積物研究 : 北方四島の津 波堆積物と北海道西部太平洋側の断層モデルの検討. 地質雑, 123, 805-817. [Takashimizu, Y., 2017, Review of the studies of tsunami deposit of Hokkaido, northern Japan: Focusing on the tsunami deposits of Northern Territory and fault models of the western Pacific coast of Hokkaido. J. Geol. 
Soc. Japan, 123, 805-817.]

高清水康博・永井 潤・岡村 聡・西村裕一, 2013, 砂丘を越えて沿岸 低地を遡上した津波による堆積モデル：北海道胆振海岸東部に 分布する 17 世紀津波堆積物の研究例. 地質雑, 119, 1-16. [Takashimizu, Y., Nagai, J., Okamura, S. and Nishimura, Y., 2013, A tsunami depositional model in coastal lowland over sand dune: An example from the 17th century tsunami deposit in the eastern Iburi coast, central Hokkaido, northern Japan. J. Geol. Soc. Japan, 119, 1-16. ]

高清水康博・仁科健二・川上源太郎・佐藤善輝・岡村 聡・ 中西 諒 …... 石丸 聡, 2017, 北海道日高海岸北部から確認された 17 世紀 の津波堆積物. 第四紀研究, 56, 1-9. [Takashimizu, Y., Nishina, K., Kawakami, G., Sato, Y., Okamura, S., Nakanishi, R.,...Ishimaru, S., 2017, Identification of a 17th-century tsunami deposit on the northern Hidaka coast, Hokkaido, northern Japan. Quatern. Res. (Daiyonki-Kenkyu), 56, 1-9.]

高清水康博 - 嵯峨山 積 - 仁科健二 - 岡 孝雄 - 中村有吾 - 西村裕一, 2007 , 北海道胆振海岸東部から確認された 17 世紀の津波堆積物. 第四紀研究, 46, 119-130. [Takashimizu, Y., Sagayama, T., Nishina, K., Oka, T., Nakamura, Y. and Nishimura, Y., 2007, A 17th-century tsunami deposit discovered on the eastern Iburi coast, Hokkaido, northern Japan. Quatern. Res. (Daiyonki-Kenkyu), 46, 119-130. ]

つじよしのぶ, 1989, 寛永 17 年 6 月 13 日 (1640VII31) 北海道駒ヶ 岳噴火による津波. 地震学会講演予稿集, 1, 261. [Tsuji, Y., 1989, Tsunami from the Eruption of Hokkaido Komagatake on July 13, 1640. Seismol. Soc. Japan, Abstr., 1, 261.]*.

Yamanaka, Y. and Tanioka, Y., 2017, Estimating the topography before volcanic sector collapses using tsunami survey data and numerical simulations. Pure Appl. Geophys., 174,
3375-3291.

Yoshii, T., Tanaka, S. and Matsuyama, M., 2017, Tsunami deposits in a super-large wave flume. Mar. Geol., 391, 98-107. 吉本充宏 - 古川竜太 - 七山 太 ・ 西村裕一 ・ 仁科健二 - 内田康人 ....... 木下博久, 2003, 海域に流入した北海道駒ヶ岳火山 1640 年岩屑 なだれ堆積物の分布と体積推定. 地質杂隹, 109, 595-606. [Yoshimoto, M., Furukawa, R., Nanayama, F., Nishimura, Y., Nishina, K., Uchida,...Kinoshita, H., 2003, Subaqueous distribution and volume estimation of the debris-avalanche deposit from the 1640 eruption of Hokkaido-Komagatake volcano, southwest Hokkaido, Japan. J. Geol. Soc. Japan, 109, 595-606.]

Williams, R., Rowley, P. and Garthwaite, M. C., 2019, Small flankfailure of Anak Krakatau Volcano caused catastrophic December 2018 Indonesian tsunami. EarthArXiv, doi: 10.31223/osf.io/u965c.

*English translation from the original written in Japanese

(執筆分担)
中西 諒 野外調査, 各種分析, 総括, 原稿執筆を担当
岡村 聡 野外調査, 研究全体における議論を担当

岡村 聡 野外調査, 研究全体における議論を担当

（著者プロフィール）

中西 諒 東京大学大気海洋研究所在籍. 13 年 北海道教育大学教育 学部札幌校卒業, $13 \sim 19$ 年 北海道札幌東豊高等学校教諭, 19 年 北 海道教育大学大学院教育学研究科修士課程を修了. 研究内容: 北海 道における津波堆積物研究.

E-mail : r-nakanishi@aori.u-tokyo.ac.jp

\section{中西 諒・岡村 聡，2019，1640 年北海道駒ヶ岳噴火による津波堆積物の分布と津波規}

模の推定. 地質雑, 125，835-851. (Nakanishi, R. and Okamura, S., 2019, Tsunami deposits from the 1640 Hokkaido Komagatake eruption, north Japan: constraints on inundation heights and numerical simulation of volcanic debris avalanche-derived tsunami. J. Geol. Soc. Japan, 125, 835-851.)

北海道太平洋沿岸西部は, 17 世紀の地震・津波の規模や波源を明らかにする上で重要な 地域である. そこで歴史記録に残っている 1640 年の駒ヶ岳噴火にともなう山体崩壊津波 の規模を推定するために, 内浦湾から胆振海岸西部にかけて 17 世紀のイベント堆積物の 分布を明らかにした. イベント堆積物の粒度・鉱物組成は海浜周辺の砂とよく類似しており, 内陸に向け薄層化・細粒化・軽量化を示す．本砂層は，内浦湾から登別にかけて 1640 年 の駒ヶ岳噴火テフラ (Ko-d) によって覆われていることから, 1640 年の駒ヶ岳山体崩壊に ともなう津波堆積物であると判断される. 現世の津波堆積物調査結果を基に各調査地点の 津波堆積物分布における浸水深 $1 \mathrm{~m}$ が妥当かを評価し, 数值シミュレーションを用いて $1.20 \mathrm{~km}^{3}$ を超える山体崩壊物流入量を再現し遡上高を求めたところ, 内浦湾沿岸から白老 周辺までは，両者の推定遡上高が調和的な結果となった．この津波規模は約 Mt 7.9-8.2 と 見積もられる.

科学論文では, 学説の検証可能性を保証することが重要です。そのため, 地質学雑誌掲載論文には, 重 要な証拠となった試料がどこで得られたかを示しているものがあります。言うまでもないことですが, 見学や採取を行う場合, 各自の責任において地権者や関係官庁への連絡と許可の取得の必要があること にご注意下さい。詳しくは，以下のサイトをご覧ください.

http://www.geosociety.jp/publication/content0073.html 